\title{
Light Emitting Diodes (LEDs) as Agricultural Lighting: Impact and Its Potential on Improving Physiology, Flowering, and Secondary Metabolites of Crops
}

\author{
Musa Al Murad ${ }^{1,2,+}$, Kaukab Razi ${ }^{1,2,+}$, Byoung Ryong Jeong ${ }^{3} \mathbb{D}$, Prakash Muthu Arjuna Samy 4 (D) and \\ Sowbiya Muneer $1, *$ \\ 1 Horticulture and Molecular Physiology Lab, School of Agricultural Innovations and Advanced Learning, \\ Vellore Institute of Technology, Vellore 632014, India; almuradmusa@gmail.com (M.A.M.); \\ hrazi8@gmail.com (K.R.) \\ 2 School of Biosciences and Technology, Vellore Institute of Technology, Vellore 632014, India \\ 3 Horticulture, Division of Applied Life Science (BK21+), Graduate School, Gyeongsang National University, \\ Jinju 52828, Korea; brjeong@gnu.ac.kr \\ 4 Department of Genetics and Plant Breeding, Faculty of Agriculture, Annamalai University, \\ Chidambaram 608002, India; geeth_prakash@yahoo.co.in \\ * Correspondence: sowbiya.muneer@vit.ac.in or sobiyakhan126@gmail.com \\ + The first two authors contributed equally to this work.
}

check for updates

Citation: Al Murad, M.; Razi, K.; Jeong, B.R.; Samy, P.M.A.; Muneer, S. Light Emitting Diodes (LEDs) as Agricultural Lighting: Impact and Its Potential on Improving Physiology, Flowering, and Secondary Metabolites of Crops. Sustainability 2021, 13, 1985. https://doi.org/ $10.3390 /$ su13041985

Academic Editor: Domenico Ronga

Received: 16 January 2021

Accepted: 9 February 2021

Published: 12 February 2021

Publisher's Note: MDPI stays neutral with regard to jurisdictional claims in published maps and institutional affiliations.

Copyright: (c) 2021 by the authors. Licensee MDPI, Basel, Switzerland. This article is an open access article distributed under the terms and conditions of the Creative Commons Attribution (CC BY) license (https:/ / creativecommons.org/licenses/by/ $4.0 /)$.

\begin{abstract}
A reduction in crop productivity in cultivable land and challenging environmental factors have directed advancement in indoor cultivation systems, such that the yield parameters are higher in outdoor cultivation systems. In wake of this situation, light emitting diode (LED) lighting has proved to be promising in the field of agricultural lighting. Properties such as energy efficiency, long lifetime, photon flux efficacy and flexibility in application make LEDs better suited for future agricultural lighting systems over traditional lighting systems. Different LED spectrums have varied effects on the morphogenesis and photosynthetic responses in plants. LEDs have a profound effect on plant growth and development and also control key physiological processes such as phototropism, the immigration of chloroplasts, day/night period control and the opening/closing of stomata. Moreover, the synthesis of bioactive compounds and antioxidants on exposure to LED spectrum also provides information on the possible regulation of antioxidative defense genes to protect the cells from oxidative damage. Similarly, LEDs are also seen to escalate the nutrient metabolism in plants and flower initiation, thus improving the quality of the crops as well. However, the complete management of the irradiance and wavelength is the key to maximize the economic efficacy of crop production, quality, and the nutrition potential of plants grown in controlled environments. This review aims to summarize the various advancements made in the area of LED technology in agriculture, focusing on key processes such as morphological changes, photosynthetic activity, nutrient metabolism, antioxidant capacity and flowering in plants. Emphasis is also made on the variation in activities of different LED spectra between different plant species. In addition, research gaps and future perspectives are also discussed of this emerging multidisciplinary field of research and its development.
\end{abstract}

Keywords: crop improvement; floral growth; lighting systems; physiological modeling; metabolic activities

\section{Introduction}

Indoor cultivation of crops is best suited for crop breeding projects that are independent of outdoor climatic variations across seasons [1]. However, plant development and physiology are solely dependent on the availability of light spectra in controlled environmental growth conditions. The beginning of doing agriculture in a controlled environment either in urban areas or by agro-industries meant that an efficient artificial lighting source 
had to be developed. For quite a long time, artificial light sources such as fluorescent lamps, filament lamps and high-pressure sodium lamps (HPS) have been used in growth chambers or greenhouses [2]. Nevertheless, these light sources consume a high amount of electrical energy and somehow cause light stress in plants, which ultimately makes them inefficient for optimal growth [3]. Therefore, a desire to control sustainable farming costs by controlling light conditions has been the subject of research.

Light-emitting diodes (LEDs) are a recent lighting technology that has entered the arena of artificial agricultural lighting. LEDs provide various advantages over the traditional lighting systems, such as longer lifetime, smaller size, higher photosynthetic efficiency, lesser thermal radiation and higher safety performance [4,5]. Indeed, LEDs also act as an optional light quality to improve plant growth, nutritional quality and yield; a systems approach has to be developed for the efficient use of LEDs in plant production and development. The direct radiation of heat by LEDs is not seen, but LEDs do produce heat that has to be effectively removed from the system for better functionality [6]. The potentials of LED lighting are many, of which the development of a species-specific light recipe for optimizing plant growth and other desirable traits are promising $[7,8]$.

Any new technology comes with its own challenges to be resolved; the case of LED technology in artificial agricultural lighting is no different. The effect of red, blue, and green light, including other combinations of various spectrums of light, has been found to be effective for plant growth and development, nutrient efficiency, pest control, the production of bioactive compounds, and the induction of flowering, etc. $[9,10]$. However, the high capitol cost and knowledge on the adequate proportions of the following lights (blue, green, red and/or their combinations) required for the optimal growth of specific plants is scarce, and whether the spectral requirements for specific plants will change over the course of time also needs attention. Since better results are obtained with spectral combinations, more work has to be conducted on wide/narrow spectral intensities of light [11,12]. Besides, the quantification of light requires the development of new techniques, software calibrations, and hardware such that the Photosynthetic Photon Flux (PPF) for LEDs are quantified accurately for intercanopy lighting. Further, the calculation of canopy volume or total energy use/cost requires radiation capture metrics. The economic viability of LEDs in agricultural lighting is of major concern. The technique is developing day by day, and as the demand increases, the supply also has to increase. Therefore, a balance between the cost of LEDs and their energy efficiency for various types of crop lighting has to be maintained such that the LEDs in artificial agriculture lighting see no setbacks. The transportation costs incurred from traditional agriculture can be cut down if locally produced products from artificial agricultural systems using LEDs are available in every locality [13]. Thus, the future of LEDs in artificial agricultural lighting is promising.

Light intensity and spectral distribution importance are well observed when the cultivation of plants under a variety of light environments is compared [1]. Light is considered to be an important driving factor for plant growth and development. It not only provides energy for driving photosynthesis, but signals downstream gene expression for substance metabolism for the acclimatization of plants towards fluctuations in environment [14]. The blue and red wavelengths supply the energy required for the growth and development of plants via photosynthesis and photoreceptors, which regulate morphogenetic events such as plant elongation, leaf expansion, stomatal opening, circadian clock, and flowering [14].

Photoreceptors of plants, namely phytochromes, cryptochromes, phototropins, ZEITL UPE (ZTL), and UV-B receptors (e.g., UVR8), regulate the transcriptional changes in response to light by sharing distinct pathways amongst each other [15]. A more complicated response of plants towards light spectra is due to the cross talk among photoreceptors via transcription factors (e.g., HY5 and PIFs) [15]. When blue and red light are used in combination, the light appears purplish gray, and for humans, the diagnosis of disease and disorder of plants under this faint light becomes difficult. This led to the idea of using a small amount of green light in agricultural lighting [13]. The light spectra, at the biochemical level, however, affect both primary and secondary metabolism and improve 
nutritional quality, carbohydrate and nitrogen metabolism, flavor production, volatile and aromatic compounds, as well as enhance plant defense mechanisms [12,16,17]. However, changes in the spectra of light can cause several changes in plant responses and metabolic processes. LEDs bring out the possibility to manipulate the growth period, plant metabolisms, defense, flowering and the amount and quantity of plant products $[18,19]$. Physiological responses of plants change with spectral changes, and it is believed that red light is involved in the assimilation of assimilates as it influences the photosynthetic apparatus [20]. Blue light is known to affect photosynthetic parameters such as chlorophyll formation, chloroplast development, etc., but the effect is largely dose dependent [21]. In some studies, it has been observed that green light exerts similar effects as blue light, through photoreceptor proteins to participate in photosynthesis [22]. However, through the inductive biological antagonistic systems, green light tends to reverse the effects of blue and red light [23]. Since green light can effectively pass through the tissues, it may engage itself in reactions not directly exposed to the light stimulus [24]. Thus, testing a large amount of light recipes is required so as to identify the optimum light regime that improves plant growth, development, nutrition, flavor flowering, and defense mechanisms. Several beneficial effects of LEDs on plants are shown in Figure 1.

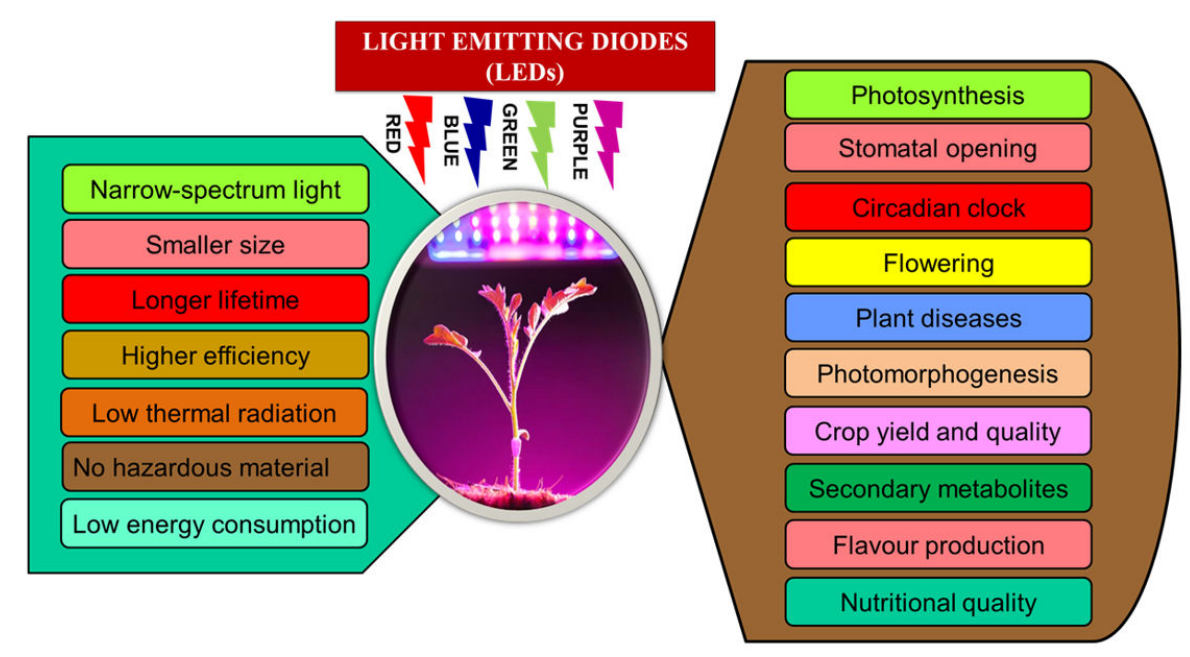

Figure 1. Schematic diagram of light emitting diode (LED) efficiency on plant growth and development. The beneficial effects of LEDs on plants include improving crop yield and quality, flavor production, nutritional quality, photosynthetic efficiency, plant defense and flowering, etc.

In the first half of this review, we discuss the physiological aspects of the supplementation of plants to different LED wavelengths and how various wavelengths impact the photosynthetic efficiency of plants and if/how various results contradict each other, thus leaving a gap to be considered for more research. In the second half of this review, we discuss the biochemical effects of LED wavelengths on plants and find out whether an effective light recipe for specific plants is better, or if a single spectrum on specific plants can be supplied to all plant species with varied wavelengths.

\section{Morphological Modeling in Plants Using LEDs}

Light assumes a crucial job in controlling plant development and advancement via photosynthesis. [25-27]. The most obvious and noticeable effect of different LED treatments is on the growth and morphological changes of plants, and these changes are a combined result of genetic expression, phytochromes, cryptochromes and phototropins in response to different light conditions $[14,28,29]$. Phytochromes, cryptochromes and phototropins are the three significant photoreceptor families that direct the declaration of different qualities because of light stimuli [29]. However, the molecular mechanism of the signal transduction via cryptochromes and phytochromes is not clearly understood. 
Several studies have been carried out for various plant species regarding their growth and development under the diversification of LED lights, but out of all, the majority of studies observed that plants mainly utilize red and blue portions of the light spectrum, as these wavelengths are effectively absorbed by the main photosynthetic pigments [30]. Far-red light is responsible for the reduction in the pigment concentration of plants [31], whereas it also leads to the enhancement of total biomass and plant elongation [32-34]. Red and far-red light interact with each other, and far-red-light LED treatment has a significant impact on various photo-physiological processes in lettuce and radish [35]. Under farred LED treatment, squash seedlings represented a significant enhancement in hypocotyl elongation [36]. Far-red LEDs supplemented with red or blue LEDs also enhanced plant height and leaf area in ageratum (Ageratum houstonianum), marigold (Tagetes erecta) and salvia (Salvia officinalis) [37]. In contrast, maximum biomass and height in buckwheat (Fagopyrum esculentum) [38] and cucumber (Cucumis sativa) seedlings [39] were observed under the treatment of blue LEDs.

Red LED light is one of the basic elements in the entire light spectrum, which is very much suitable and enough for normal plant growth and photosynthesis. Therefore, any variation in red or far-red radiation and their ratios is perceived by phytochromes [40], which may impact photo morphogenetic processes in plants. Red light has more potential in plant growth and production as compared to far-red light and is more desirable because [41] it increases plant yield [42], reduces nitrate concentration [43] and increases vitamin C concentration [44] in plants. Contrasting results of red light were observed where red light hindered the transition to flowering in basil [45], whereas it induced upward or downward leaf curling in tomato (Solanum Lycopersicum) [46]. It has been observed that the supplementation of red LEDs, combined with a small portion of blue LEDs, at low to moderate light intensities, resulted in improved growth in lettuce $[32,47,48]$ and Chinese cabbage [49]. Red LEDs supplemented with blue and far-red LEDs exhibited an increase in height, biomass, and leaf area in kohlrabi, mustard, red pakchoi and tatsoi [50]. Further, Pinho et al. [34] reported that, in lettuce, far-red light supplied together with red and blue LEDs enhanced potassium, calcium, and magnesium uptake. An enhancement in lettuce growth under far-red lighting was the result of an increase in leaf area and, subsequently, due to improved light interception [51]. Hence, supplemental far-red LEDs, at specific portions, should be considered while designing lighting systems for plant factories.

Along with red light required for photosynthesis, blue light is also a necessary light element required to increase growth and reduce shade avoidance responses, including excessively elongated stems [52]. Blue light LEDs have significant effects on green vegetable morphology, growth, photosynthesis, and antioxidant system response by the activation of the cryptochromes system and by matching chlorophyll and carotenoid absorption spectra [12]. Blue LED light also plays a major role in improving the nutritional quality of green vegetables by reducing nitrate contents $[6,53]$ and stimulating antioxidant status, e.g., increasing phenolic compounds [6,54-56], ascorbic acid [41,53], carotenoids [31,57], anthocyanin contents and leaf coloration $[31,34,58]$, thereby affecting leaf coloration. Blue light contributes enormously to plant production [59] by increasing the vegetative growth [41] and pigment concentration [59] in plants. Red LEDs supplemented with blue LEDs resulted in improved growth and yield for strawberry [60,61], whereas the same treatment resulted in increased fruit yield in capsicum [62]. However, for marigold and salvia plants, monochromatic blue LEDs caused an increase in plant height but reduced the number of flower buds and blooming period [63].

Research conducted regarding the outcomes of red and blue wavelengths on plants has already come up with the view that red LEDs enormously affect plant growth by increasing plant fresh and dry weight, plant height, and leaf area [54,63-65]. Unlike red LEDs, blue LED treatments indirectly affect plant growth by influencing photosynthetic function, chlorophyll formation and chloroplast development. $[54,64,66]$. However, a few studies claim that the combination of both red and blue LEDs has a more positive impact on the plant growth of various vegetables, such as lettuce, when compared with red 
LEDs alone $[21,26,34,66,67]$, whereas a few other relative studies have reported contrasting results $[54,68]$. Until now, the majority of studies conducted were focused on specific ratios of blue and red LEDs, leading to inconsistent results, so it is now important to understand the response of plants and their growth under different conditions of red and blue LEDs.

Like blue and red lights, green light also comes up with many desirable factors required in plant production, which include the promotion of growth [69], a reduction in nitrate concentration [9] and the elevation of saccharide concentration in plants. Early studies have indicated that green LED responses are oftentimes mediated by well-described light sensing systems [70,71]. According to some genetic and/or photo physiological experiments, researchers have demonstrated that some green light reactions are not effortlessly recognized by the present known set-up of light receptors [72]. In a study by Son and Oh [48], they determined the leaf morphology, transmittance, cell division rate, and leaf anatomy of lettuce cultivars under treatments with green LEDs, and observed enhanced growth of the two lettuce cultivars. In another study by Snowden et al. [52] and Bugbee [73], they tried to reveal that green light enters deeper into leaves and canopies, and thus fluctuating plant growth and development; however, its effects may decline with increasing photosynthetic fluxes. Samuolienè et al. [43] worked on baby leaf lettuce and found that under the combination of red and blue LEDs, green LED light of wavelength $530 \mathrm{~nm}$ promoted the accumulation of a-carotene and anthocyanins. However, significant effort will need to be put into the development of LED lighting models for different green vegetables and lettuce cultivars. One outcome identified that when photosynthetic photon flux was kept consistent, lettuce developed in a blend of red, blue, and green LED light had bigger leaf territory and higher new and dry shoot mass than those developed solely under red or blue light alone [74,75]. Their finding demonstrated that although red and blue light are progressively powerful for advancing photosynthesis, green light may infiltrate plant leaves more efficiently and increase carbon fixation [75,76]. It can therefore be concluded from previous reports that blue, green, and red-light LEDs are the main light colors to positively impact the yield, growth, and nutrient quality in plants. Nevertheless, in specific conditions, some other light colors can also be constructive, such as far-red light, orange light and ultraviolet-A (UVA) light. Future work on light color manipulation has a possible role in producing lamps and covers of greenhouses to influentially support yield, growth and nutrition in plants.

The effect of light quality likely differs, bestowing to plant species, plant growth stages and environmental conditions such as PPF, the composition of medium and ventilation [77,78]. However, comprehensive studies are necessary regarding the correlations between light quality and growth conditions. Therefore, research has to be conducted to identify the ideal ratio of red/blue(R/B) under a combination of red and blue light-emitting diodes (LEDs). Additionally, a study on responses of plants on the sole-source of light spectrums has to be investigated in other important horticultural crops to standardize for optimal light recipes. Moreover, a significant demand remains regarding how to optimize spectral quality for plant growth, development, mineral nutrition, and metabolism.

\section{Photosynthetic Efficiency in Plants under LEDs}

Light is also a vital energy source for the process of photosynthesis and other metabolic processes for the better growth and development of plants. A change in the quality of light has a reflective effect on plant growth, particularly on photosynthesis [79,80]. The range of photosynthetically active radiation (PAR) overlaps the complete visible spectrum $(400-700 \mathrm{~nm})[81,82]$. However, the red and blue regions are assumed to be the most indispensable for photosynthesis [83]. Red light comprises photons of lower energy which are readily utilized by plants during photosynthesis [13]. Blue light, apart from imparting energy to photosystems, promotes photosynthesis by stimulating stomatal opening [84] and regulating chloroplast relocation and transcription [85]. Conversely, high light intensity causes photo oxidative damage in the leaves [86,87] and has been observed to reduce photosynthesis by hampering chlorophyll biosynthesis [88]. 
Various plant photoreceptors that include phytochromes, cryptochromes and phototropins are responsible for perceiving the light required for photosynthesis and also act as an environmental signal, responding to its intensity, wavelength, and direction [89]. Among these pigments, phototropins are non-photosynthetic, cryptochromes are blue light sensitive and phytochromes are red light sensitive [90]. Phototropins direct phototropism, chloroplast migration and stomatal opening [91], whereas cryptochromes guide photomorphogenesis [92]. Phytochromes also play an important role in germination, shade avoidance, etiolation and de-etiolation and sense the relative abundance of red and far-red light to coordinate various photo responses [93]. A large number of crops have been studied and grown under the availability and absence or a combination of both red and blue light at different wavelengths [94,95]. An increase in photosynthetic rate was reported in wheat [96], spinach [67], lettuce [97], cucumber [21], Chinese cabbage [49,98] and chrysanthemum [99] under a combination of red and blue LEDs, with the proportion of red LEDs being $80-90 \%$. Nevertheless, photosynthetic rate was also observed to be increased under high photosynthetic photon flux density (PPFD) of green LEDs in lettuce [69]. High intensity monochromatic red and blue LED treatments were also found to enhance the rate of photosynthesis in sunflower [100]. However, less facts are known on the integrity of the combined effect of green, red and blue LEDs, with less or no experimental evidence available concerning the expression of multiprotein complexes for the promotion of induction of photosynthesis.

Muneer et al. [101] worked on Lactuca sativa L. under different light intensities at three wavelengths of green, red and blue LEDs, and investigated thylakoid multiprotein complex proteins (MCPs), stomata and other relative photosynthetic parameters. They observed that lettuce grown solely under a high intensity of blue LED light showed enhanced photosynthetic parameters including stomatal opening and closing and other photosynthetic activity than red and green LEDs. However, other than lettuce, several crops including rice [102] also observed a lower photosynthetic rate when grown under red LEDs. One of the reasons for this decreased photosynthesis under red LED light seems to be the changes in thylakoid multiprotein complexes, which are directly associated with photosynthesis. The decreased chlorophyll and carotenoid content lead to lowered photosynthesis [75]. It was also observed in their study that the number of stomata increased more in plants grown under blue LEDs compared to plants grown under low light intensities and other LEDs, which is in correlation with previous studies [103]. The closure and reduced number of stomata under red LED light might be due to the defoliation of leaves under low light intensity during the growth of lettuce [104].

However, until date limited research has been conducted on the expression of thylakoid proteins under different intensities of light and light sources. Several proteins are involved in the primary reactions of photosynthesis occurring in the thylakoid membrane. Photosynthetic proteins are majorly organized in four multi subunit protein complexes: PSI, PSII, ATP synthase complex and cytochrome b6/f (cyt b6/f) complex [105]. Muneer at al. [101] reported that the expression of PSII-core dimer under blue LEDs was enhanced in lettuce, whereas it was inhibited under green LED light conditions [106]. The inhibition of PSI and PSII under green LEDs with low light intensity suggests the involvement of an unidentified protein related to the transport of substances in plants or due to reduced amounts of core antenna Chl-protein complexes [107]. Additionally, RuBisCo was expressed more under high blue light intensity, which could be associated with an increase in the amount of $\mathrm{N}$ content accompanied by the induction of chlorophyll content, or it might also be due to the wider and thinner expansion of palisade and sponge parenchyma.

Stomatal opening is regulated by a combination of light intensity and light quality [101]. Stomata are capable of adjusting their pores rapidly in response to the everchanging environment $[108,109]$, and stomatal movement is governed by light $[110,111]$. Light energy transformation, light signal transduction, membrane ion transport and an abundance of plasma membrane $\mathrm{H}^{+}$-ATPase (HA) regulate the process of stomatal opening 
or closing [112] in leaves. Overexpression of plasma membrane H+ -ATPase in leaves promotes stomatal opening induced by light intensity and quality [113], thereby enhancing plant growth. Previous studies have concluded that plasma membrane $\mathrm{H}^{+}$-ATPase plays a critical role in regulating stomatal opening [114] and plays a crucial and primary role in regulating plant growth [115] and responses to environmental stimuli [116]. The opening and closing of stomatal guard cells are regulated by phototropins present in stomatal guard cells in response to blue light stimuli [117] to allow the uptake of $\mathrm{CO}_{2}$ to facilitate photosynthesis $[112,118]$, which further leads to transpirational loss of water through leaves. In order to minimize the water loss, guard cells tend to close the stomatal pore during heavy sunlight or other high light conditions. Distinctive mechanisms underlie the opening and closing of stomata at different light wavelengths [110,119].

Hogewoning et al. [21] observed that the stomatal conductance (gs) of cucumber leaves was highest by 50\% under blue light and 50\% under red light. Similarly, the highest gs of lettuce was observed under blue light [120]. Shimazaki et al. [112] also reported that values of gs in leaves illuminated with a combination of red and blue light are larger than leaves illuminated under red or blue light alone, which was in agreement with the results reported by other researchers $[21,39,121]$. Similarly, cucumbers grown under monochromatic red light had very low values of gs $[21,66]$ and were in agreement with the results observed by Wang et al. [120]. Several studies have also observed that stomatal conductance was significantly influenced by altering the LED treatment in Japanese arrowroot [122] and lettuce $[67,123]$. In another study, it was observed that monochromatic blue LEDs and blue LEDs supplemented with a small ratio of red LED light improved the conductance of stomata significantly in several plant species, such as chrysanthemum [99], cucumber [21] and lettuce [101]. The above studies propose the contributions of phytochromes and cryptochromes in stomatal movements and their opening and closing [124]. The opening of stomata due to blue light can thus concomitantly subsidize in the improvement of crop production [21,101]. Goins et al. [96] have also reported that the photosynthetic rates were higher in leaves of wheat under red and blue LEDs. However, Yorio et al. [67] stated that photosynthetic rates were not improved when stomatal opening was stimulated under red LEDs supplemented with blue light. In lettuce, Kim et al. [74] detected that gs was responsive to the spectral quality of light during growth and, in the short-term, it was not directly coupled to dry matter growth. In another study, Wang et al. [120] observed that the photosynthetic rate in lettuce leaves improved with an increase in blue to red LED ratio, concomitant to an increase in gs and stomatal density. Similar results were also observed in rice [26] and cucumber [21,39]. Therefore, the effect of blue light and blue to red LED ratio on leaf photosynthesis and dry matter productivity remains unclear, and we presume that effects may be species-specific.

The biosynthesis of the three most important plant pigments, namely chlorophylls, carotenoids and anthocyanins, is light dependent. Chlorophyll is produced by the reduction of its precursor "protochlorophyllide" only in the occurrence of light [125], whereas anthocyanin biosynthesis is due to the upstream light-dependent stimulation of "chalcone synthase" gene expression [126]. Many related studies have been conducted where different combinations of red and blue LEDs resulted in elevated chlorophyll contents in Chinese cabbage [98], capsicum [62], strawberry [60] and broccoli [127] seedlings. Chlorophyll content was found to be highest under pure red LED treatments in kale [57] and strawberry [60]. The biosynthesis of chlorophyll and other photosynthetic pigments requires different quality and intensity of light. Chlorophyll is one of the basic pigments and its concentration and composition can directly influence the rate of photosynthesis [128,129]. Wang et al. [64] found that blue light improves the gene expression of $\mathrm{MgCH}$ (Mg-chelatase), GluTR (glutamyltRNA reductase) and $\mathrm{FeCH}$ (Ferrochelatase) and they regulate the synthesis of chlorophyll $[130,131]$, whereas red light on the other hand is not conducive to the formation of chlorophyll because of the reduction in tetrapyroles precursor 5-aminolevulinic acid [132]. In a study conducted by Fan et al. [94] on chlorophyll biosynthesis in non-heading Chinese cabbage, they came up with similar findings that under red 
light treatment chlorophyll synthesis was lowest, and these results were consistent with previous studies [131].

Future research should consequently explore effect of supplementary green LED light with red and blue lighting on the physiological metabolism of plants, such as photosynthesis, and the modulation of secondary metabolism right below and close to the blue light spectrum. Though not as strongly absorbed by chlorophylls, green light penetrates further into leaf tissue and is absorbed by chloroplasts in the lower leaf canopy, which in turn increases photosynthesis. Moreover, flavonoid synthesis under narrow band LED lighting necessitates closer exploration, as thus far, most research has been related to the use of UV light and fluorescent light(FL). Supplementary research into the modulatory effect of LED lighting on the genes responsible for coding key enzymes in biosynthetic pathways, such as the isoprenoid or phenylpropanoid pathways, will accelerate the development of microgreens as functional foods.

\section{Flowering in Plants under LEDs}

Depending on the influence of night length on flowering, plants have been categorized into various photoperiodic response groups. Most of the floriculture crops belong to one of the three photoperiodic classes, i.e., long day plants (LDPs), short day plants (SDPs), and day-neutral plants $[133,134]$. The plants that are day-neutral can be induced to flower irrespective of the photoperiod, assuming other environmental and cultural factors are in favor. However, flowering in LDPs is induced when the night length is shorter than some critical length, whereas the induction of flowering in SDPs is when night length is longer than some critical duration [135]. Furthermore, within the photoperiodic classes, plants can be categorized as qualitative or obligate response (based on whether the photoperiod is required for flowering) and quantitative or facultative response (if the photoperiod simply accelerates flowering). Most of the ornamental plants are required to be in flower to be more marketable, and that too on specific, pre-determined market dates [136]. During peak sales season, day lengths are often short in temperate regions, and therefore growers have to resort to creating artificial long days for inducing the flowering of crops that are photoperiodic and to be ready by the market date. Short day plants are maintained in a vegetative state by providing artificial long days for the production of vegetative stem cuttings and for preventing premature flowering. Manipulation of the photoperiod can help in reducing the production costs as well as the production time, and improve the overall crop quality [134]. Traditionally, incandescent lamps (INC) have been used for growing photoperiodic crops. However, the use of incandescent bulbs as a source of lighting for flowers has been phased out due to their inefficiency $(90 \%$ of energy is released as heat), and they have been replaced by the more efficient light emitting diodes (LEDs) [137]. Thus, LEDs can be useful in creating prescription lighting which is tailored for SDPs and LDPs to control the flowering process.

The cut flower industry is largely dependent on the ability to strictly control the flowering of obligate short-day plants such as chrysanthemum, which can be induced to flower throughout the year. During long day seasons, blackouts can induce flowering, and day length extension or night break illumination with artificial light can inhibit flowering [138]. In a study where chrysanthemum cuttings were illuminated with blue, green, red and white LED light, it was seen that blue light supplementation resulted in the appearance of flower buds in 20.5 days, whereas other LED lights did not induce flowering even until 35 days [139]. This study also suggested that flowering does not follow the day length response threshold under blue light supplementation. Similarly, the illumination of ever bearing strawberry plants HS138 with blue LEDs with a peak wavelength of 450 $\mathrm{nm}$ promoted flowering as compared to red LEDs with a peak wavelength of $660 \mathrm{~nm}$ [140]. The potency of blue light to promote flowering was further tested by illuminating ever bearing strawberry plants with blue light of three different wavelengths $(405,450$ and $470 \mathrm{~nm}$ ) and red light of three different wavelengths $(630,660$ and $685 \mathrm{~nm})$. The study reported an increase in flowering from all blue LED wavelengths as compared to red 
LEDs [141]. However, in another study where chrysanthemum "Reagen" was illuminated with several wavelength of LEDs, the inhibition of flowering was found to happen at a wavelength of $596 \mathrm{~nm}$ (amber light), which reduced the expression of flowering related genes in chrysanthemum such as Flowering Locus T(FT)-like gene (CmFTL3) [142]. Blue and far-red light have no effect on the flowering of chrysanthemum [142]. In contrast, a study by Nissim-levi et al. [137] showed that blue light caused the inhibition of flowering, but the effect depended on the duration of illumination. On reducing the illumination duration, blue light appeared to be inefficient in preventing flowering as compared to red and white light [137]. A similar study on Chenopodium rubrum L supplemented with red and white light reported that flowering was delayed on the supplementation of red and white LEDs [143]. More research needs to be undertaken to check whether the increased intensity of blue light is able to compensate for the duration of lighting and can prevent flowering under natural shorter lighting hours, and whether this involves CmFTL3.

The inhibition of flowering by LED light is also variety dependent. For example, the flowering of autumn-flowering chrysanthemum "Jimba" was seen to be inhibited by red light, but red light had no effect on the summer-to-autumn flowering "Iwa no Hakusen" variety [144]. Flowering could have been prevented for both cultivars by illumination with a combination of red and far-red light [144]. The disadvantage of using a single wavelength is that even a small difference of $10-20 \mathrm{~nm}$ can impact the flowering initiation capacity and other physiological parameters [144]. Therefore, a wide range of LEDs of varied wavelengths have to be used to identify the optimal wavelength for a particular plant species. In marigold, the number of visible flower buds was much higher in fluorescent light plus red LED (FLR) illumination as well as the control (fluorescent light), and it was fives time greater than that in blue or red LED illumination [62]. Similarly, no flower bud formation was seen in salvia grown under monochromatic blue or red LEDs [62]. The duration of blooming period in both marigold and salvia was also affected by the different light qualities [62]. A study on ever bearing strawberry illuminated with blue, green and red LEDs reported that the blue LEDs resulted in the highest number of flower clusters, and the red LEDs resulted in the lowest number of flower clusters [145]. Cyclamen treated with monochromatic blue, red and blue plus red LEDs showed that the number of flower buds and open flowers in cyclamen were highest in the case of blue plus red LED treatment as opposed to other LEDs [146]. It is already established that blue and red light via cryptochromes and phytochromes, respectively, induce the photomorphogenic response in plants [147], with flowering being a complex phenomenon where light interacts via photoreceptors and involves endogenous circadian clock and flowering genes [148]. Therefore, the molecular interactions between these elements have to be studied.

Phytohormones also play a crucial role in the flower induction process. In Arabidopsis thaliana, it was reported that gibberellic acid (GA) induced the signal for flower initiation [149,150]. Similarly, in petunia, light quality was seen to affect the GA content [151]. The role of blue and red light in enhancing and inhibiting shoot elongation via modulating the GA content was also reported [152]. In contrast, the application of GA did not induce flowering in petunia under red light [153]. Therefore, GA cannot be appointed as the major flower imitating hormone. The interaction of light and GA also promoted flowering measurements of dahlia and Asiatic lily [154]. The interaction of light and GA has been found to affect similar pathways that are involved in seed germination and dormancy [155]. Hence, it is also imperative that light and GA interact in a similar manner to affect the pathways involved in growth and flowering. Williams and Morgan [156] reported that far-red light can induce GA to hasten flowering in sorghum. In a further study, the application of cytokinin $(\mathrm{CK})$ was seen to induce flowering in petunia grown under red light. Fukuda et al. [153] further reported that CK and blue light can induce signals to promote flowering via floral induction genes. Similarly, Magar et al. [145] reported the activation of endogenous GA levels under red LEDs, resulting in the inhibition of flowering and the activation of CK levels by blue LEDs, resulting in an increase in flowering in ever bearing strawberry [145]. The findings of Lin [157] reported that signals from cryptochromes 
and phytochromes control the floral induction genes FLOWER LOCUS T (FT) and SUPPRESSOR OF OVEREXPRESSION OF CONSTANS1 (SOC1) in Arabidopsis. Further, in Arabidopsis, CK was seen to promote flowering by transcriptional activation of the $F T$ and SOC1 genes [158]. However, in contrast to red light illumination, blue light was reported to increase SOC1-like gene expression in petunia [159]. Therefore, it can be said that red light photoreceptors and phytochromes and blue light photoreceptors and cryptochromes stimulate the GA and CK activity, respectively, to inhibit/initiate flowering response under red and blue LEDs, respectively, by the suppression or activation of floral induction genes. However, the mechanism between light quality and plant hormone metabolism and its subsequent effect on the flowering of plants is yet to be illustrated. More research has to be carried out by the use of multi array LED lamps with multiple spectrums in combination with GA and CK to see its effect on plant growth and flowering, as the aspects change with change in species.

Supplying artificial light in the middle of the night (night interruption, NI) is known to regulate the flowering of species sensitive to photoperiods $[160,161]$. NI delivers photoperiodic lighting by breaking up the long dark period, which leads to an altered long day condition for plants (LD) [162]. Thus, the introduction of NI in the short day (SD) season is seen to induce flowering in LDPs, therefore allowing early marketing or seed production and also delaying the flowering of SD plants in a manner similar to the natural LD conditions [163]. Thus, it can be said that NI induces flowering more effectively than adding the same quantity or duration of light at the end of the photoperiod [161]. In herbaceous SDPs such as Dendranthema grandiflorum [164,165] and Kalanchoe blossfeldiana [166], the delaying of flowering by NI is achieved by halting plants in a vegetative growth stage. NI with low light intensity induces flowering during the juvenile stage in Cymbidium aloifolium [167]. The response of flowering plants towards the light quality supplied through NI has been studied in Oryza sativa [168], Arabidopsis thaliana [169], Antirrhinum majus [170], Eustoma grandiflorum [160], Dendranthema grandiflorum [165,171], Pelargonium hortorum [172], and Petunia hybrida [161].

In petunia illuminated with white LEDs under long day (LD), short day (SD) and short day with $4 \mathrm{~h}$ night interruption (NI) with blue (NI-B), green (NI-G), red (NI-R), far-red (NI-Fr) and white (NI-W) LEDs, it was reported that flowering was induced in LD, NI-G, NI-R, NI-Fr, and NI-W [164]. The flowering percentage was highest in LD (100\%), which was followed by NI-R and NI-Fr (33.3\% each) and both NI-G and NI-W with $16.6 \%$ each [161]. The flowering in NI was lower than LD, which can be attributed to the low light quality used in NI. It was reported earlier that flowering in A. thaliana is delayed by monochromatic blue light through its influence on cryptochromes [173]. The red light induced inhibition of flowering is mediated by the red-light pathway, whereas the blue and far-red pathways are known to mediate the blue or far-red dependent suppression of the red pathway as well as the blue or far-red dependent promotion of flowering [174]. Far-red, blue and red LEDs were effective in promoting flowering in A. thaliana in NI experiments; however, red LEDs were seen to be the least effective [175]. In contrast, Park et al. [161] reported that green, red, far-red and white LEDs could promote flowering and vice versa with blue LEDs in an NI experiment. This may be attributed to the differential effects of light quality on day extension by NI.

In geranium, under different NI treatments such as NI-R, NI-G, NI-B, NI-W, and NI-Fr, Park et al. [172] reported that all plants flowered in all the treatments, and the percentage of flowering was not significantly affected by light quality during NI. The number of flowers per plant was lowest under NI-Fr, the length of flower stalk was highest in NI-B, and length decreased in NI-W and SD compared to other treatments [172]. NI, when used in combination with PAR (green, blue, red and white) with photon fluxes lower than the compensation point, does not necessarily help vegetative growth, but hastens the flowering even in day neutral plants such as germanium. Further, Park et al. [176] also reported flowering in chrysanthemum subjected to various NI treatments (NI-R, NI-G, NI-B, NI-W, NI-Fr), except NI-R treatment shed onto the shoot tip. However, flowering was seen to 
be induced when NI-R was shed onto the youngest mature leaf or old leaves [176]. This implies that the usual $\mathrm{R}$ light suppression of flowering during NI in SD plants may not be applicable if NI is irradiated on young and old leaves. It was also reported that NI-R irradiated plants onto the youngest mature leaf had more flowers per plant as compared to SD. This is explained by the study of Park et al. [177], who stated that when the carbon demand linked to plant growth is exceeded by the carbohydrate production, a higher number of flowers per plant is visible due to the fact that vegetative growth is relatively longer. Kang et al. [178] reported that two varieties of kalanchoe, namely "lipstick" and "spain", reacted differently to the NI treatments. The "lipstick" variety showed no flowering in any of the photoperiodic treatments, whereas the "spain" variety showed differentially or fully developed flowering in the treatment of NI-B. Further, it has to be seen how morphogenesis and flowering are affected by NI quality and intensity in other plants as well. Not only the appropriate quality but the positioning of NI is also important for optimum flowering and plant growth. Therefore, more practical consideration has to be given to the NI strategy.

Theoretically, flowering is induced when one or more of the flowering promoter genes (PHYA and CRY1) are expressed in high levels [179]. The perception of blue light signal by CRY1 or CRY2 in Arabidopsis thaliana stimulates the expression of FT and SUPPRESSOR OF OVEREXPRESSION OF CO 1 (SOC1) by increasing CONSTANS (CO) protein stabilization, which is known to cause meristematic tissues to differentiate and lead to early flowering [180]. Florigen is the hypothetical signal that arises from the leaf, causing the initiation of shoot apex flowering [181]. Flowers are seen to bloom early if the "gene switch" for initiating floral buds is turned on by a specific light quality [176]. In a study on Petunia hybrida, Park et al. [161] reported that phy A, phyB and cry 1 genes were highly expressed in the NI-G, NI-B, and NI-R compared to LD and SD, which acted as the positive and negative control, respectively. Similarly, the expression of $c r y 1, F T L$, and AFT was high under NI-B, NI-R and NI-Fr, suggesting that flowering induction is dependent on the differential expression of the flower induction genes [161]. Similarly, in geranium, whose flowering is highly light sensitive, it was observed that under normal LD, the photoreceptor genes phyA, cry 1 and $A F T$ were highly expressed, except phyB and FTL [172]. Additionally, the expression of phyA, phyB, cry1, AFT and FTL was significantly higher in NI treatment with different light qualities, except under NI-B. In NI-B treatment, the expression of phyA, phyB, cry1, AFT, and FTL was lower than under LD [172]. The expression of these genes under NI conditions indicates that genes are activated during the night, and the transcription factors may assert a role in it by being involved in the light-dependent/independent phase of photochemical reactions. Additionally, it can be seen that NI could induce photoreceptor gene expression and/or induce stress response in plants, which was observed under NI-B, where the expression of photoreceptor genes was not seen [172]. Higuchi et al. [138] reported that NI-Fr treatment in chrysanthemum reversed the flowering response initiated by NI-R. The role of phyB in the inhibition of flowering in plants under NI-R and the subsequent reversion of flowering response by NI-Fr in chrysanthemum were also reported [171]. Higuchi et al. [172] also reported that knockdown of phyB led to an increase in the upregulation of the flower inducer (florigen) and the downregulation of the flowering inhibitor (antiflorigen), and led to an early flowering response in chrysanthemum. In another study on chrysanthemum, it was reported that the transcriptional factor phy $A$ was slightly increased in treatments under LD, NI-B, NI-Fr and NI-W, which showed flowering responses (Park et al., 2019a). However, the expression of $c r y 1, p h y B$ and TFL was not significant. The low expression of these genes may be attributed to the combined effect of these genes with flower inhibiting genes, namely anti-florigenic FT/TFL1 family protein (AFT). Despite the high level of expression of $p h y A$, the non-flowering of LD treatment may be due to the higher expression levels of phyB and TFL in this treatment [176], since phyB is known to act with phyD and phyE in a partially redundant manner so as to induce R light dependent flowering inhibition [182]. However, cry1 and cry2 are known to act redundantly in mediating the blue light dependent initiation of flowering [174]. Park et al. [183] reported that, 
in chrysanthemum, NI-B treatment induced flowering with higher levels of expression of photoreceptor genes such as phyA, cry1, and $F T$, probably due to the presence of flowering inhibitor genes $p h y B$ and $A F T$ at lower levels. Flowering observed in NI-Fr treatment with high levels of phyB and $A F T$ is attributed to the presence of a high expression of FT in this treatment. However, the high expression levels of phyB in NI-G, NI-W and NI-R treatments explain the lack of flowering in these conditions [183]. The explanations for this may be the difference in genotype used, the experimental environment, the sample collection time, the plant part from which the sample was collected, etc. The genetic mechanism that is involved between the light quality and gene expression leading to flowering has to be elucidated. A diagrammatic representation of the possible effects of different LED lights on the gene expression of flowering genes and the effect of NI by various LEDs on the expression of flowering genes is shown in Figure 2.

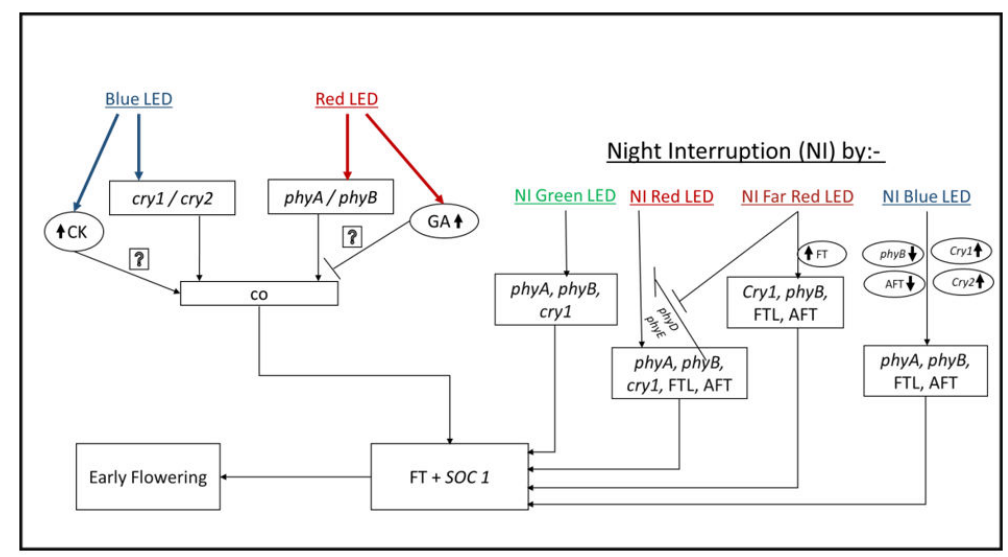

Figure 2. Effect of blue and red LEDs on the expression of flowering genes and their correlation with the phytohormone cytokinin and gibberellins in inducing early flowering in plants. The effect of night interruption by different wavelengths of LEDs as shown in the figure also leads to expression of flowering genes. However, $p h y B$ is sometimes seen to inhibit flowering by the interplay of $p h y D$ and $p h y E$, which is, however, inhibited by the increased expression of FT gene under NI by far-red LED. Additionally, the presence of phyB and AFT genes in lower amounts allows the overexpression of cry1 and cry1 genes, which leads to flowering in plants. (NI indicates night interruption; Phy indicates phytochrome; Cry indicates cryptochrome; FT indicates flowering locus; AFT indicates antiflorigen; SOC indicates suppressor of cytokine).

\section{Impact of LEDs on Secondary Metabolites of Plants and Their Subsequent Antioxidant Capacities}

The generation of free radicals in plants is synonymous to the occurrence of oxidative damage. This, however, is delayed or inhibited by compounds known as plant secondary metabolites [184]. Secondary metabolites of plants exist in a strong intermolecular covalently bound form with long chain polymers [185]. A diet which includes a high amount of bioactive phytochemicals acts as a potential countermeasure to curb the dose of oxidative compounds and simultaneously induces oxidative damage repair in tissue in situ $[186,187]$. Recent research has been performed in establishing the efficiency of dietary antioxidants in moderating cellular level responses of the immune system and inflammation in animal models and human trials [188]. Light is known to stimulate the activation of enzymes and regulate their synthesis pathways, such as PAL (phenylalanine ammonia-lyase) activity in phenyl propanoid pathways, which are anticipated to promote the accumulation of bioactive compounds in plants [189]. Light, being the only source of energy for photosynthesis, drives the photosynthetic biosynthesis and photomorphogenesis [25]. Furthermore, the relation between phytochemical biosynthesis and photosynthates amount is well established [65]. Hence, rational light conditions are very essential for the accumulation of bioactive compounds [7]. 
The presence of specific photoreceptors in plants is meant to either harvest light energy for driving photosynthesis or to respond to changes in the quality and quantity of light [127]. Specific genes encode specific photoreceptors; a similarity of high degree is, however, seen amongst photoreceptors of the same family [190]. Photoreceptors affect plant morphology and development include phytochromes (PHYA and PHYE), cryptochromes (CRY1 to CRY3), phototropins (PHOT1 and PHOT2) and UV-B resistance locus 8 (UVR8). The synthesis of phytochemicals [50] and the controlling of plant physiological responses [191] are under the influence of phytochromes, whereas processes such as the regulation of stomatal opening, the production of biomass and the biosynthesis of anthocyanins [31], carotenoids [192], and chlorophyll [193] molecules are under the influence of plant cryptochromes. The downregulation of LeHY5 (positive regulator for fruit pigmentation) results in defective light responses in plants, such as the inhibition of seedling photomorphogenesis, loss of thylakoidal organization and a reduction in the accumulation of carotenoids [194]. Conversely, the downregulation of LeCOP1LIKE (negative regulator of fruit pigmentation) expression leads to overstated photomorphogenesis, dark green leaves and the elevation of fruit carotenoid levels [195]. Therefore, the effect of such signal transduction genes can be allocated to enhance the nutritional value and quality of fruits, affecting the phenotype expression, physiological metabolism and antioxidant activity. However, it is necessary that more research must be carried out to find out the effect of individual or combined wavelengths of light on the expression of signal transduction genes to elucidate a universal pathway.

For minimizing oxidative stress in systemic tissues, detoxifying mechanisms developed by plants comprise of antioxidants and reactive oxygen species (ROS) scavengers such as superoxide dismutase (SOD), catalase (CAT), ascorbate peroxidase (APX), and peroxidase [196]. Lettuce varieties supplemented with short term red light $(638 \mathrm{~nm})$ possessed substantial antioxidant capacity, and the effect of supplemental light was variety dependent [9]. However, a long duration of LED lighting can also put plants under stress [197]. The level of accumulation of antioxidants in lettuce leaves is a determinant of the sensitivity of different varieties of lettuce towards supplemental light. Similarly, the total phenol and free radical scavenging activity of rice hull increased on irradiation with far-infra red light, resulting in increased antioxidant activity [198]. Meir et al. [199] reported that the reduction in peroxide level is due to the strong reducing power in tissues, which also enhances the antioxidant activity. The availability of a variety of natural antioxidants such as vitamin $\mathrm{C}$, anthocyanin, phenolic compounds and their synergistic interaction causes the enhancement of antioxidant effectiveness of natural antioxidants. Osmoprotectants such as proline also play a role in regulating oxidative stress by keeping the concentration of ROS within a compatible range for the plants under stress [200]. Blue light increases the accumulation of proline in tomato as compared to red and green light-treatments for 21 days. The amount of polyphenol compounds and ROS scavenging enzymes in tomato also increases in blue light treatment as compared to red and green light treatments [11]. In basil, blue LED light enhanced secondary metabolites such as total ascorbate, total phenolic compounds, anthocyanin, flavonoid content, and antioxidant capacity [201]. Photosynthetic pigments absorb blue light more efficiently than other wavelengths of light [202]. A short-term exposure to blue light before sunrise can effectively improve the quality and promote the production of strawberry plants [203]. However, the blue light activated signaling pathways involved need to be elucidated to understand developmental modifications in plants towards a particular wavelength of light.

Carotenoids are secondary metabolites that are vital pigments of plants, functioning as antenna pigments and thereby minimizing damage from the active triplet state of chlorophyll to the photosynthetic components [204]. Carotenoids have an important role as photosensitizers as they scavenge the reactive oxygen species produced in plants [205]. Based on their structures, carotenoids are classified into two groups: carotenes, which contain hydrogen and carbon and are thus hydrocarbons (e.g., $\beta$-carotene and lycopene), and xanthophylls, which have additional oxygen atoms (e.g., lutein, neoxanthin, zeaxan- 
thin, and violaxanthin) [206]. The two main components of carotenoids, which include lutein and $\beta$-carotene, have roles in curing age-related eye diseases, cardiovascular diseases and lung cancer $[207,208]$. Although the prevalence of zeaxanthin is only in minor concentrations, it combines with lutein in leaf tissues to perform an important antioxidant role [209]. Therefore, the consumption of vegetables rich in carotenoids is recommended for the healthy functioning of the body. Supplemental blue light increases the ascorbic acid content in lettuce [210]. In baby leaf lettuce, supplemental blue or UVA light for a short period enhances anthocyanin accumulation, whereas supplemental blue light increases the concentration of carotenoids (lutein and $\beta$-carotene) and supplemental red light increases phenolic compounds, whereas supplemental far-red light increases biomass but reduces the concentration of phytochemicals [31]. Therefore, an appropriate ratio of blue, red or far-red light has to be devised so as to obtain an optimum content of phytochemicals and biomass of plants grown under white light. Additionally, the different ratios obtained have to be tested upon plants in both greenhouses and growth chambers to identify where the difference of effect lies and whether the LED source of light is more efficient than conventional ones. In contrast, cucumber seedlings grown in greenhouses with red or yellow LED light irradiation showed an increased concentration of carotenoids [64]. Pea seedlings irradiated with red light had a significant increase in $\beta$-carotene concentration, and the Trolox equivalent antioxidant capacity (TEAC) value of pea seedlings radiated under red light was the highest as compared to blue, white and dark light, suggesting that the antioxidant capacity of pea seedlings was enhanced under red light irradiation [65]. Red and blue light also increased lutein and $\beta$-carotene biosynthesis in kale, thus increasing their concentrations [57]. Thirty-three percent of blue light irradiation to mustard, beet, and parsley microgreens showed the highest content of carotenoids (lutein, neoxanthin, violaxanthin, and $\alpha$ - and $\beta$ carotene) as compared to 8,16 and $25 \%$ of blue light. However, the content of $\alpha$-tocopherol showed an increase at a rather lower dosage (162) of blue light [193]. This highlighted the effect of increased light intensity affecting the biochemical transformation of one pigment to another, such as violaxanthin into zeaxanthin, thus ultimately influencing the carotenoid content [211]. A correlation between blue light supplementation and the accumulation of carotenoids has been reported in green leafy vegetables [212]. Carotenoid content in 15d pre harvest kale shoots was found to be improved under red: blue light as compared to that under white light supplementation [213]. Moreover, in mustard microgreens, green light in addition to red and blue light also showed a positive effect on the lutein/zeaxanthin ratio and $\beta$-carotene content $[54,55]$. The evidence showed that light intensity may also be equally important to light quality in carotenoid biosynthesis $[55,213]$. Understanding this will help researchers to identify and prioritize gaps for future research, especially on the influence of specific monochromatic LED lights on gene expression, phenolic compounds and carotenoid compounds.

Phenolic compounds are a major class of secondary metabolites in plants that are further grouped into phenolic acids and polyphenols, which are found combined with mono and polysaccharides, linked to one or more phenolic group, or can be found as derivatives, such as esters or methyl esters [131]. Members of phenolic compounds such as flavonoids, phenolic acids and tannins are designated as the main dietary phenolic compounds [214]. Various studies have correlated phenolic compound content to the antioxidant potential of fruits and vegetables $[215,216]$. The mode of action of phenolic compounds is either functioning as direct antioxidants or modulating the efficacy and production of other antioxidant compounds that are present in the body [217]. The ability of phenolic compounds to confer antioxidant capacity to plants is attributed to the capacity of scavenging free radicals, the donation of hydrogen atoms, electrons, or in chelating metal cations [218]. The supplementation of red: blue light in red leaf basil microgreens results in a 4-5-fold increase in the synthesis of caffeic acid and rosmaric acid, respectively, as compared to white LED light [219]. In lettuce, chlorogenic acid synthesis, which occurs via the cryptochrome-mediated pathway, was more effective under red light than blue light [54]. The same study also reported an increasing synthesis of chlorogenic acid on 
increasing intensity of light, irrespective of it being red and blue light. In pea sprouts, blue light was reported to increase the concentration of phenolic compounds such as hydroxybenzoic acids (Gallic, o-phthalic, and p-hydroxbenzoic) and heterocyclic amines (chlorogenic acid CGA, caffeic, p-coumaric, and ferulic); three flavonoids (rutin, phloridzin, and kaempferol); and resveratrol [220]. In another study by Nam et al. [221], blue light was found to be more efficient at increasing the total phenolic compounds (TPC), total flavonoid content (TFC), anthocyanin content and antioxidant capacity in common buck wheat sprouts. These results are concordant with the studies that suggested that blue LED light has a key role in enhancing the synthesis of phenolic compounds [222].

Several studies have projected blue light as the most effective lighting source for the synthesis of flavonoid compounds by the stimulation of PAL, CHS (chalcone synthesis), and DFR (dihydroflavonol-4-reductase) and gene expression [223]. Soybean sprouts grown under LED lighting conditions were found to contain high isoflavones content as compared to those grown under fluorescent light [224]. This was later confirmed by Azad et al. [202], who reported that blue light is the best for the accumulation of secondary metabolites (isoflavones, such as daidzin, glycitin, genistin, daidzein, glycerin, and genistein) in plants, thus enhancing the antioxidant activity in soybean sprouts. Another study on a medicinal tea in china, Cyclocarya paliurus, supplemented with four different LED lights, viz. blue, red, green and white, showed that blue light was able to cause the maximum accumulation of flavonoids such as kaempferol, isoquercetin and quercetin as compared to other wavelengths of light [225]. The gene expression of key enzymes (PAL, 4CL and CHS) involved in phytochemical biosynthesis and their relation to flavonoid content in leaves have been reported, throwing light on the modulatory effect that LEDs might have had on the genes coding these enzymes [225]. To understand the modulatory influence of LED lights on gene expressions such as gene coding enzymes in biosynthetic pathways will categorically help to reveal the mechanisms behind the increased or altered levels of phytochemicals and the development of antioxidant-rich vegetables solely by the use of LED light.

Moreover, anthocyanins are known to be a subgroup of flavonoids and are pigments conferring red, purple, and blue colors to the plants, and they are commonly associated with sugars such as gylcosides; however, aglycones (anthocyanidins) also exist [208]. The capacity of anthocyanin to absorb oxygen radicals is almost four times greater than that of vitamin E and ascorbic acid [226]. Despite their health benefits, anthocyanins also indicate the quality of commercial fruits, vegetables and ornamentals [34]. Anthocyanins have strong anti-inflammatory potential, contributing towards improved gut immunity and health [195]. They play a key role in photosynthesis to protect plants against excessive light [227]. Light is a prerequisite for anthocyanin accumulation, wherein different spectral qualities are known for modulating its synthesis [228]. Studies have emphasized the importance of blue light in modulating the synthesis of anthocyanin [31]. In support of this, tomato plants supplemented with blue light were seen to accumulate a high amount of anthocyanin [29]. However, the cryptochrome-mediated regulation of anthocyanin synthesis has the requirement of active phytochrome for full expression, which, however, can be met by lower levels of phytochrome A or phytochrome B [229]. Therefore, the possibility of other wavelengths of LED light influencing anthocyanin synthesis cannot be understated [6,7]. A study was carried out on cabbage varieties "Kinshun" and "Red Rookie" seedlings to study the effects of blue, blue-green, green and red LED lights on the biosynthesis of phytochemicals. It was found that red light increased the total anthocyanin content in "red rookie", whereas the anthocyanin content in "Kinshun" remained the same regardless of the light quality [58]. A general trend of the positive effect of supplemental LED light on the anthocyanin concentration in red and light-green leaf lettuce was found to be of the order $505>455>470>535 \mathrm{~nm}$ [43], which was in concordance with the study of Zhang and Folta [230], who reported the reversal of the effect of the blue light-induced accumulation of anthocyanin by green light. Similarly, green LED light was reported to decrease blue light-induced anthocyanin accumulation, while far-red and blue light were able to enhance anthocyanin accumulation with increasing intensity in kale, broccoli and 
beet microgreens [127]. This was further established by a study on Arabidopsis thaliana, where it was established that $C R Y 1$ activated by blue light can initiate flavosemiquinone signaling states, which are converted to an inactive form by green light [23].

The concept of controlled environmental agriculture has also attracted the use of LEDs in space farming in order to be self-sufficient during long duration space flights. In this regard, the benefits of growing leafy vegetables under LEDs for the dietary well-being of astronauts during outer space exploration programs cannot be undermined. As the astronauts often come across various radiations such as solar protons and helium ions beyond Earth's magnetosphere, galactic cosmic ray high atomic number (HZE) particles and high proton fluxes form solar proton events, and this may cause numerous health issues leading to the risk of cancer in astronauts [231]. However, the consumption of naturally available antioxidants is known to surpass the radiation effect and can be entrusted to be effective in enhancing healing from oxidative damage [232]. Anthocyanin, a member of the flavonoid family, is ranked to be of high antioxidant capacity. Stutte et al. [35] studied the effect of LEDs on the anthocyanin content and the consequent antioxidant potential of red leaf lettuce. They found that the plants growing under LEDs were $30 \%$ larger in total biomass as compared to fluorescent lamps. Furthermore, the anthocyanin content was found to be higher in the red and blue combination as compared to the other combinations of spectral light. Similarly, the antioxidants also increased by $20 \%$ on the addition of blue light to the spectral combination. Thus, the study suggested that the bio protectant abilities of red leaf lettuce can be improved by spectral adjustments, hinting towards the potential of using LED lighting for improving the bio protectant capabilities of leafy vegetables for consumption during long duration space flights. However, photo regulatory control of the synthesis and degradation of flavonoids that presume bio protective properties has to be identified.

\section{Conclusions}

Light is considered to be the primary environmental factor that regulates the growth, development, pigmentation and morphogenesis of plants. When the availability of light is limited due to geographical location, climate or outdated facilities, the demand for a controlled environment for agriculture arises, which is met by the use of LEDs as artificial lighting sources for plant growth and development. The use of LEDs has seen a tremendous jump amongst plant growers due to their efficiency and the low cost of operations. Blue, red, green, and far-red wavelengths of LEDs have been seen to positively affect the morphology, photosynthetic efficiency, and flowering in plants in addition to the production of secondary metabolites, thereby protecting plants against oxidative stress. However, different researchers resort to using different recipes of wavelengths across different species to obtain optimum results, and the results vary across and within species. Thus, a combined LED light recipe has to be obtained which will give growers a better and detailed idea of the different wavelengths and intensities of light to be used. Furthermore, the role of LEDs has been linked to the activation or suppression of genes related to varied functions, such as bioactive compound synthesis, the induction or inhibition of flowering, etc. However, the mechanisms behind these interactions between LED wavelengths and genes have to be elucidated such that there is scope for the alteration or manipulation of such genes to improve the productivity and quality of crops grown under a variety of LED illuminations. In conclusion, LED technology holds the key to the future revolution in plant growth and development.

Author Contributions: Conceptualization, writing—original draft preparation, M.A.M.; and K.R.; writing-review and editing, B.R.J., S.M.; and P.M.A.S.; project administration, S.M.; funding acquisition, S.M.; All authors have read and agreed to the published version of the manuscript. 
Funding: This work was supported by DST-SERB (project no. SRG/2020/000170), Govt. of India. The authors would also like to thank Balaji Poly Packs, Karnataka, India, for funding to carry out part of this research work. The authors would also like to acknowledge VIT for providing 'VIT SEED GRANT' to carry out the initial part of this research work.

Institutional Review Board Statement: Not applicable.

Informed Consent Statement: Not applicable.

Acknowledgments: The authors apologize to those researchers whose work has not been cited in the review.

Conflicts of Interest: The authors declare no conflict of interest regarding the publication of this paper.

\section{References}

1. Monostori, I.; Heilmann, M.; Kocsy, G.; Rakszegi, M.; Ahres, M.; Altenbach, S.B.; Szalai, G.; Pál, M.; Toldi, D.; Simon-Sarkadi, L.; et al. LED Lighting-Modification of growth, metabolism, yield and flour composition in wheat by spectral quality and intensity. Front. Plant Sci. 2018, 9, 605. [CrossRef]

2. Tibbitts, T.; Morgan, D.; Warrington, I. Growth of lettuce, spinach, mustard, and wheat plants under four combinations of high-pressure sodium, metal halide, and tungsten halogen lamps at equal PPFD. J. Am. Soc. Hortic. Sci. 1983, 108, 622-630.

3. Randall, W.C.; Lopez, R.G. Comparison of supplemental lighting from high-pressure sodium lamps and light-emitting diodes during bedding plant seedling production. HortScience 2014, 49, 589-595. [CrossRef]

4. Schuerger, A.C.; Brown, C.S.; Stryjewski, E.C. Anatomical features of pepper plants (Capsicum annuum L.) grown under red light emitting diodes supplemented with blue or far-red light. Ann. Bot. 1997, 79, 273-282. [CrossRef] [PubMed]

5. Bula, R.J.; Morrow, R.C.; Tibbitts, T.W.; Barta, D.J.; Ignatius, R.W.; Martin, T.S. Light-emitting diodes as a radiation source for plants. HortScience 1991, 26, 203-205. [CrossRef] [PubMed]

6. Bian, Z.H.; Cheng, R.F.; Yang, Q.C.; Wang, J.; Lu, C. Continuous light from red, blue, and green light-emitting diodes reduces nitrate content and enhances phytochemical concentrations and antioxidant capacity in lettuce. J. Am. Soc. Hortic. Sci. 2016, 141, 186-195. [CrossRef]

7. Bian, Z.H.; Yang, Q.C.; Liu, W.K. Effects of light quality on the accumulation of phytochemicals in vegetables produced in controlled environments: A review. J. Sci. Food Agric. 2015, 95, 869-877. [CrossRef]

8. Wei, H.; Hu, J.; Liu, C.; Wang, M.; Zhao, J.; Kang, D.I.; Jeong, B.R. Effect of supplementary light source on quality of grafted tomato seedlings and expression of two photosynthetic genes. Agronomy 2018, 8, 207. [CrossRef]

9. Samuolienè, G.; Brazaityte, A.; Sirtautas, R.; Novičkovas, A.; Duchovskis, P. The Effect of Supplementary LED Lighting on the Antioxidant and Nutritional Properties of Lettuce. Acta Hortic. 2011, 952, 835-841. [CrossRef]

10. Dong, C.; Fu, Y.; Liu, G.; Liu, H. Growth, photosynthetic characteristics, antioxidant capacity and biomass yield and quality of wheat (Triticum aestivum L.) exposed to LED light sources with different spectra combinations. J. Agron. Crop Sci. 2014, 200, 219-230. [CrossRef]

11. Kim, K.; Kook, H.S.; Jang, Y.J.; Lee, W.H.; Seralathan, K.K.; Chae, J.C. The effect of blue-light-emitting diodes on antioxidant properties and resistance to Botrytis cinerea in tomato. J. Plant Pathol. Microbiol. 2013, 4, 203.

12. Olle, M.; Viršile, A. The effects of light-emitting diode lighting on greenhouse plant growth and quality. Agric. Food Sci. 2013, 22, 223-234. [CrossRef]

13. Massa, G.D.; Kim, H.H.; Wheeler, R.M.; Mitchell, C.A. Plant productivity in response to LED lighting. HortScience 2008, 43, 1951-1956. [CrossRef]

14. Chen, M.; Chory, J.; Fankhauser, C. Light signal transduction in higher plants. Ann. Rev. Genet. 2004, 38, 87-117. [CrossRef]

15. Su, J.; Liu, B.; Liao, J.; Yang, Z.; Lin, C.; Oka, Y. Coordination of cryptochrome and phytochrome signals in the regulation of plant light responses. Agronomy 2017, 7, 25. [CrossRef]

16. Colquhoun, T.A.; Schwieterman, M.L.; Gilbert, J.L.; Jaworski, E.A.; Langer, K.M.; Jones, C.R. Light modulation of volatile organic compounds from petunia flowers and select fruits. Postharvest Biol. Technol. 2013, 86, 37-44. [CrossRef]

17. Darko, É.; Heydarizadeh, P.; Schoefs, B.; Sabzalian, M.R. Photosynthesis under artificial light: The shift in primary and secondary metabolism. Philos. Trans. R. Soc. B 2014, 369, 20130243. [CrossRef] [PubMed]

18. De Salvador, F.R.; Scarascia Mugnozza, G.; Vox, G.; Schettini, E.; Mastrorilli, M.; Bou Jaoudé, M. Innovative photoselective and photo luminescent plastic films for protected cultivation. Acta Hortic. 2008, 801, 115-121. [CrossRef]

19. Schettini, E.; de Salvador, F.R.; Scarascia-Mugnozza, G.; Vox, G. Radiometric properties of photoselective and photoluminescent greenhouse plastic films and their effects on peach and cherry tree growth. J. Hortic. Sci. Biotechnol. 2011, 86, 79-83. [CrossRef]

20. Baroli, I.; Price, G.D.; Badger, M.R.; Caemmerer, S. The contribution of photosynthesis to the red light. Plant Physiol. 2008, 146, 737-747. [CrossRef] [PubMed]

21. Hogewoning, S.W.; Trouwborst, G.; Maljaars, H.; Poorter, H.; van-Ieperen, W.; Harbinson, J. Blue light does-responses of leaf photosynthesis, morphology, and chemical composition of Cucumis sativus grown under different combinations of red and blue light. J. Exp. Bot. 2010, 6, 3107-3117. [CrossRef] [PubMed] 
22. Swatz, T.E.; Corchnoy, S.B.; Christie, J.M.; Lewis, J.W.; Szundi, I.; Brigs, W.R.; Bogomolni, R.A. The photocycle of flavin-binding domain of the blue light photoreceptor phototropin. J. Biol. Chem. 2001, 276, 3693-36500.

23. Folta, K.M.; Maruhnich, S.A. Green light a signal to slow down or stop. J. Exp. Bot. 2007, 58, 3099-3111. [CrossRef] [PubMed]

24. Sun, J.D.; Nishio, J.N.; Vogelmann, T.C. Green light drives $\mathrm{CO}_{2}$ fixation deep within leaves. Plant Cell Physiol. 1998, $39,1020-1026$. [CrossRef]

25. Walters, R.G. Towards an understanding of photosynthetic acclimation. J. Exp. Bot. 2005, 56, 435-447. [CrossRef] [PubMed]

26. Matsuda, R.; Ohashi-Kaneko, K.; Fujiwara, K.; Kurata, K. Analysis of the relationship between blue-light photon flux density and the photosynthetic properties of spinach (Spinacia oleracea L.) leaves with regard to the acclimation of photosynthesis to growth irradiance. Soil Sci. Plant Nutr. 2007, 53, 459-465. [CrossRef]

27. Perez, C.P.; Ulrichs, C.; Huyskens-Keil, S.; Schreiner, M.; Krumbein, A. Composition of carotenoids in tomato fruits as affected by moderate UV-B radiation before harvest. Int. Symp. Tomato Trop. 2008, 821, 217-222. [CrossRef]

28. Lillo, C.; Appenroth, K.J. Light regulation of nitrate reductase in higher plants: Which photoreceptors are involved? Plant Biol. 2001, 3, 455-465. [CrossRef]

29. Giliberto, L.; Perrotta, G.; Pallara, P.; Weller, J.L.; Fraser, P.D.; Bramley, P.M. Manipulation of the blue light photoreceptor cryptochrome 2 in tomato affects vegetative development, flowering time, and fruit antioxidant content. Plant Physiol. 2005, 137, 199-208. [CrossRef]

30. Ouzounis, T.; Razi Parjikolaei, B.; Fretté, X.; Rosenqvist, E.; Ottosen, C.O. Predawn and high intensity application of supplemental blue light decreases the quantum yield of PSII and enhances the amount of phenolic acids, flavonoids, and pigments in Lactuca sativa. Front. Plant Sci. 2015, 6, 19. [CrossRef] [PubMed]

31. Li, Q.; Kubota, C. Effects of supplemental light quality on growth and phytochemicals of baby leaf lettuce. Environ. Exp. Bot. 2009, 67, 59-64. [CrossRef]

32. Lee, M.J.; Son, K.H.; Oh, M.M. Increase in biomass and bioactive compounds in lettuce under various ratios of red to far-red LED light supplemented with blue LED light. Hortic. Environ. Biotechnol. 2016, 57, 139-147. [CrossRef]

33. Pinho, P.; Jokinen, K.; Halonen, L. The influence of the LED light spectrum on the growth and nutrient uptake of hydroponically grown lettuce. Light. Res. Technol. 2016, 100, 4377-4382. [CrossRef]

34. Stutte, G.W.; Edney, S. Photoregulation of Bioprotectant Content of Red Leaf Lettuce with Light-emitting Diodes. Hortscience 2009, 44, 9-82. [CrossRef]

35. Tamulaitis, G.; Duchovskis, P.; Bliznikas, Z.; Breive, K.; Ulinskaite, R.; Brazaityte, A.; Novičkovas, A.; Žukauskas, A. High-power light-emitting diode based facility for plant cultivation. J. Phys. D Appl. Phys. 2005, 38, 3182. [CrossRef]

36. Yang, Z.C.; Kubota, C.; Chia, P.L.; Kacira, M. Effect of end-of-day farred light from a movable LED fixture on squash rootstock hypocotyl elongation. Sci. Hortic. 2012, 136, 81-86. [CrossRef]

37. Heo, J.W.; Lee, C.W.; Paek, K.Y. Influence of mixed LED radiation on the growth of annual plants. J. Plant Biol. 2006, 49, 286-290. [CrossRef]

38. Lee, S.W.; Seo, J.M.; Lee, M.K.; Chun, J.H.; Antonisamy, P.; Arasu, M.V.; Suzuki, T.; Al-Dhabi, N.A.; Kim, S.J. Influence of different LED lamps on the production of phenolic compounds in common and Tartary buckwheat sprouts. Ind. Crop. Prod. 2014, 54, 320-326. [CrossRef]

39. Hernández, R.; Kubota, C. Physiological responses of cucumber seedlings under diffe rent blue and red photon flux ratios using LEDs. Environ. Exp. Bot. 2016, 121, 66-74. [CrossRef]

40. Demotes-Mainard, S.; Peron, T.; Corot, A. Plant responses to red and far red lights, applications in horticulture. Environ. Exp. Bot. 2016, 121, 4-21. [CrossRef]

41. Li, H.; Tang, C.; Xu, Z.; Liu, X.; Han, X. Effects of different light sources on the growth of non-heading Chinese cabbage (Brassica campestris L.). J. Agric. Sci. 2012, 4, 262-273. [CrossRef]

42. Lu, N.; Maruo, T.; Johkan, M.; Hohjo, M.; Tsukakoshi, S.; Ito, Y.; Ichimura, T.; Shinoara, Y. Effects of supplemental lighting with light-emitting diodes (LEDs) on tomato yield and quality of single-truss tomato plants grown at high planting density. Environ. Control Biol. 2012, 50, 63-74. [CrossRef]

43. Samuolienè, G.; Sirtautas, R.; Brazaitytė, A.; Duchovskis, P. LED lighting and seasonality effects antioxidant properties of baby leaf lettuce. Food Chem. 2012, 134, 1494-1499. [CrossRef]

44. Bliznikas, Z.; Zukauskas, A.; Samuolienè, G.; Viršilè, A.; Brazaitytè, A.; Jankauskienè, J.; Duchovskis, P.; Novičkovas, A. Effect of supplementary pre-harvest LED lighting on the antioxidant and nutritional properties of green vegetables. Acta Hortic. 2012, 939, 85-91. [CrossRef]

45. Tarakanov, I.; Yakovleva, O.; Konovalova, I.; Paliutina, G.; Anisimov, A. Light-emitting diodes: On the way to combinatorial lighting technologies for basic research and crop production. Acta Hortic. 2012, 956, 171-178. [CrossRef]

46. Ouzounis, T.; Heuvelink, E.; Ji, Y.; Schouten, H.J.; Visser, R.G.F.; Marcelis, L.F.M. Blue and red LED lighting effects on plant biomass, stomatal conductance, and metabolite content in nine tomato genotypes. Acta Hortic. 2016, 1134, 251-258. [CrossRef]

47. Chin, L.Y.; Chong, K.K. Study of high power light emitting diode (LED) lighting system in accelerating the growth rate of Lactuca sativa for indoor cultivation. Int. J. Phys. Sci. 2012, 7, 1773-1781.

48. Son, K.H.; Oh, M.M. Leaf shape, growth and antioxidant phenolic compounds of two lettuce cultivars grown under various combinations of blue and red light-emitting diodes. HortScience 2013, 48, 988-995. [CrossRef] 
49. Avercheva, O.; Berkovich, Y.A.; Smolyanina, S.; Bassarskaya, E.; Pogosyan, S.; Ptushenko, V.; Erokhin, A.; Zhigalova, T. Biochemical, photosynthetic and productive parameters of Chinese cabbage grown under blue-red LED assembly designed for space agriculture. Adv. Space Res. 2014, 53, 1574-1581. [CrossRef]

50. Samuolienè, G.; Brazaitytè, A.; Sirtautas, R.; Viršilè, A.; Sakalauskaitè, J.; Sakalauskienè, S.; Duchovskis, P. LED illumination affects bioactive compounds in romaine baby leaf lettuce. J. Sci. Food Agric. 2013, 93, 3286-3291. [CrossRef]

51. Kubota, C.; Chia, P.; Yang, Z.; Li, Q. Applications of far-red light emitting diodes in plant production under controlled environments. Acta Hortic. 2012, 952, 59-66. [CrossRef]

52. Snowden, M.C.; Cope, K.R.; Bugbee, B. Sensitivity of seven diverse species to blue and green light: Interactions with photon flux. PLoS ONE 2016, 11, e0163121. [CrossRef] [PubMed]

53. Xin, J.; Liu, H.; Song, S.; Chen, R.; Sun, G. Growth and quality of Chinese kale grown under different LEDs. Agric. Sci. Technol. 2015, 16, 68-69.

54. Johkan, M.; Shoji, K.; Goto, F.; Hashida, S.; Yoshihara, T. Blue light-emitting diode light irradiation of seedlings improves seedling quality and growth after transplanting in red leaf lettuce. HortScience 2010, 45, 809-1814. [CrossRef]

55. Son, K.H.; Oh, M.M. Growth, photosynthetic and antioxidant parameters of two lettuce cultivars as affected by red, green, and blue light-emitting diodes. Hortic. Environ. Biotechnol. 2015, 56, 639-653. [CrossRef]

56. Taulavuori, E.; Taulavuori, K.; Hyöky, V.; Oksanen, J.; Julkunen-Tiitto, R. Species-specific differences in synthesis of flavonoids and phenolic acids under increasing periods of enhanced blue light. Environ. Exp. Bot. 2016, 121, 145-150. [CrossRef]

57. Lefsrud, M.G.; Kopsell, D.A.; Sams, C.E. Irradiance from distinct wavelength light-emitting diodes affect secondary metabolites in kale. HortScience 2008, 43, 2243-2244. [CrossRef]

58. Mizuno, T.; Amaki, W.; Watanabe, H. Effects of monochromatic light irradiation by LED on the growth and anthocyanin contents in leaves of cabbage seedlings. Acta Hortic. 2011, 907, 179-184. [CrossRef]

59. Sergejeva, D.; Alsina, I.; Duma, M.; Dubova, L.; Augspole, I.; Erdberga, I.; Berzina, K. Evaluation of different lighting sources on the growth and chemical composition of lettuce. Agron. Res. 2018, 16, 892-899.

60. Samuolienè, G.; Brazaitytè, A.; Urbonavičiūtè, A.; Šabajevienè, G.; Duchovskis, P. The effect of red and blue light component on the growth and development of frigo strawberries. Zemdirb. Agric. 2010, 97, 99-104.

61. Choi, H.G.; Moon, B.Y.; Kang, N.J. Effects of LED light on the production of strawberry during cultivation in a plastic greenhouse and in a growth chamber. Sci. Hortic. 2015, 189, 22-31. [CrossRef]

62. Gangadhar, B.H.; Mishra, R.K.; Pandian, G.; Park, S.W. Comparative study of color, pungency, and biochemical composition in chili pepper (Capsicum annuum) under different light-emitting diode treatments. HortScience 2012, 47, 1729-1735. [CrossRef]

63. Heo, J.; Lee, C.; Chakrabarty, D.; Paek, K. Growth responses of marigold and salvia bedding plants as affected by monochromic or mixture radiation provided by a Light-Emitting Diode (LED). Plant Growth Regul. 2002, 38, 225-230. [CrossRef]

64. Wang, H.; Gu, M.; Cui, J.; Shi, K.; Zhou, Y.; Yu, J. Effects of light quality on CO2 assimilation, chlorophyll-fluorescence quenching, expression of Calvin cycle genes and carbohydrate accumulation in Cucumis sativa. J. Photochem. Photobiol. B Biol. 2009, 96, 30-37. [CrossRef]

65. Wu, M.; Hou, C.; Jiang, C.; Wang, Y.; Wang, C.; Chen, H. Anovel approach of LED light radiation improves the antioxidant activity of pea seedlings. Food Chem. 2007, 101, 1753-1758. [CrossRef]

66. Savvides, A.; Fanaurakis, D.; van leparan, W. Co-ordination of hydraulic acid stomatal conductances across the light qualities in cucumber leaves. J. Exp. Bot. 2012, 63, 1135-1143. [CrossRef] [PubMed]

67. Yorio, N.C.; Goins, G.D.; Kagie, H.R. Improving spinach, radish, and lettuce growth under red light-emitting diodes (LEDs) with blue light supplementation. HortScience 2001, 36, 380-383. [CrossRef]

68. Heo, J.W.; Kang, D.H.; Bang, H.S.; Hong, S.G.; Chun, C.; Kang, K.K. Early growth, pigmentation, protein content, and phenylalanine ammonia-lyase activity of red curled lettuces grown under different lighting conditions. Korean J. Hortic. Sci. Technol. 2012, 30, 6-12. [CrossRef]

69. Johkan, M.; Shoji, K.; Goto, F.; Hahida, S.; Yoshihara, T. Effect of green light wavelength and intensity on photomorphogenesis and photosynthesis in Lactuca sativa. Environ. Exp. Bot. 2012, 75, 128-133. [CrossRef]

70. Banerjee, R.; Schliecher, E.; Meier, S.; Viana, R.M.; Pokorny, R.; Ahmed, M.; Bittl, R.; Batschauer, A. The signaling state of Arabidopsis cryptochrome 2 contains flavin semiquinone. J. Biol. Chem. 2007, 282, 14916-14922. [CrossRef]

71. Wang, C.L.; Yang, H.; Chen, M.H.; Wang, Y.R.; Li, F.J.; Luo, C.; Zhao, S.Y.; He, D. Real-time quantitative analysis of the influence of blue light on citrinin biosynthetic gene cluster expression in Monascus. Biotechnol. Lett. 2012, 34, 1745-1748. [CrossRef]

72. Goggin, D.E.; Steadman, K.J. Blue and green are frequently seen: Responses of seeds to short-and mid-wavelength light. Seed Sci. Res. 2012, 22, 27-35. [CrossRef]

73. Bugbee, B. Towards an optimal spectral quality for plant growth and development: The importance of radiation capture. Acta Hortic. 2016, 1134, 1-12. [CrossRef]

74. Kim, H.H.; Goins, G.D.; Wheeler, R.M.; Sager, J.C. Green-light supplementation for enhanced lettuce growth under red-and blue light-emitting diodes. HortScience 2004, 39, 1617-1622. [CrossRef]

75. Kim, H.H.; Goins, G.D.; Wheeler, R.M.; Sager, J.C. A comparison of growth and photosynthetic characteristics of lettuce grown under red and blue light-emitting diodes (LEDs) with and without supplemental green LEDs. Acta Hortic. 2004, 659, 467-475. [CrossRef] 
76. Terashima, I.; Fujita, T.; Inoue, T.; Chow, W.S.; Oguchi, R. Green light drives leaf photosynthesis more efficiently than red light in strong white light: Revisiting the enigmatic question of why leaves are green. Plant Cell Physiol. 2009, 50, 684-697. [CrossRef]

77. Hahn, E.J.; Kozai, T.; Paek, K.Y. Blue and red light-emitting diodes with or without sucrose and ventilation affect in vitro growth of Rehmannia glutinosa plantlets. J. Plant Biol. 2000, 43, 247-250. [CrossRef]

78. Avercheva, O.V.; Berkovich, Y.A.; Erokhin, A.N.; Zhigalova, T.V.; Pogosyan, S.I.; Smolyanina, S.O. Growth and photosynthesis of Chinese cabbage plants grown under light-emitting diode-based light source. Russian J. Plant Physiol. 2009, 56, 14-21. [CrossRef]

79. Neff, M.M.; Fankhauser, C.; Chory, J. Light: An indicator of time and place. Genes Dev. 2000, 14, 257-271. [PubMed]

80. Fukuda, N.; Fujitan, M.; Ohta, Y.; Sase, S.; Nishimura, S.; Ezura, H. Directional blue light irradiation triggers epidermal cell elongation of abaxial side resulting in inhibition of leaf epinasty in geranium under red light condition. Sci. Hortic. 2008, 115, 176-182. [CrossRef]

81. McCree, K.J. Physiological Plant Ecology I; Lange, O.L., Nobel, P.S., Osmond, C.B., Ziegler, H., Eds.; Springer: Berlin/Heidelberg, Germany, 1981; pp. 41-55.

82. Whitmarsh, J.; Govindjee. Concepts in Photobiology; Singhal, G.S., Renger, G., Sopory, S.K., Irrgang, K.-D., Govindjee, Eds.; Narosa Publishing House: New Delhi, India, 1999; pp. 11-51.

83. Yeh, N.; Chung, J.P. High-brightness LEDs-Energy efficient lighting sources and their potential in indoor plant cultivation. Renew. Sustain. Energy Rev. 2009, 13, 2175-2180. [CrossRef]

84. Roelfsema, M.R.G.; Hedrich, R. In the light of stomatal opening: New insights into 'the Watergate'. New Phytol. 2005, 167, 665-691. [CrossRef]

85. Lin, C. Blue light receptors and signal transduction. Plant Cell 2002, 14, S207-S225. [CrossRef]

86. Ilieva, I.; Ivanova, T.; Naydenov, Y.; Dandolov, I.; Stefanov, D. Plant experiments with light-emitting diode module in Svet space greenhouse. Adv. Space Res. 2010, 46, 840-845. [CrossRef]

87. Wei, H.; Zhao, J.; Hu, J.; Jeong, B.R. Effect of supplementary light intensity on quality of grafted tomato seedlings and expression of two photosynthetic genes and proteins. Agronomy 2019, 9, 339. [CrossRef]

88. Aarti, D.; Tanaka, R.; Ito, H.; Tanaka, A. High light inhibits chlorophyll biosynthesis at the level of 5-aminolevulinate synthesis during de- etiolation in cucumber (Cucumis sativa) cotyledons. Photochem. Photobiol. 2007, 83, 171-176. [CrossRef] [PubMed]

89. Dong, C.; Fu, Y.; Liu, G.; Liu, H. Low light intensity effects on the growth, photosynthetic characteristics, 2 antioxidant capacity, yield and quality of wheat (Triticum aestivum L.) 3 at different growth stages in BLSS. Adv. Space Res. 2014, 53, 1557-1566. [CrossRef]

90. Lorrain, S.; Genoud, T.; Fankhauser, C. Let there be light in the nucleus! Curr. Opin. Plant Biol. 2006, 9, 509-514. [CrossRef]

91. Briggs, W.R.; Christie, J.M. Phototropins 1 and 2: Versatile plant blue light receptors. Trends Plant Sci. 2002, 7, 204-210. [CrossRef]

92. Sancar, A. Structure and function of DNA photolyase and cryptochrome blue-light photoreceptors. Chem. Rev. 2003, 103, 2203-2238. [CrossRef] [PubMed]

93. Smith, H. Physiological and ecological function within the phytochrome family. Annu. Rev. Plant Biol. 1995, 46, 289-315. [CrossRef]

94. Fan, X.X.; Zang, J.; Xu, Z.G.; Guo, S.R.; Jiao, X.L.; Liu, X.Y.; Gao, Y. Effects of different light quality on growth, chlorophyll concentration and chlorophyll biosynthesis precursors of non-heading Chinese cabbage (Brassica campestris L.). Acta Physiol. Plant. 2013, 35, 2721-2726. [CrossRef]

95. Lin, K.H.; Huang, M.Y.; Huang, W.D.; Hsu, M.H.; Yang, Z.W.; Yang, C.M. The effects of red, blue and white light-emitting diodes on the growth, development, and edible quality of hydroponically grown lettuce (Lactuca sativa L. Var. Capitata). Sci. Hortic. 2013, 150, 86-91. [CrossRef]

96. Goins, G.D.; Yorio, N.C.; Sanwo, M.M.; Brown, C.S. Photomorphogenesis, photosynthesis, and seed yield of wheat plants grown under red light-emitting diodes (LEDs) with and without supplemental blue lighting. J. Exp. Bot. 1997, 48, 1407-1413. [CrossRef]

97. Shimizu, H.; Saito, Y.; Nakashima, H.; Miyasaka, J.; Ohdoi, K. Light environment optimization for lettuce growth in plant factory. In Proceedings of the 18th World Congress of the International Federation of Automatic Control (IFAC), Milano, Italy, 28 August-2 September 2011; pp. 605-609.

98. Avercheva, O.V.; Bassarskaya, E.M.; Zhigalova, T.V.; Berkovich, Y.A.; Smolyanina, S.O.; Leont'eva, M.R.; Erokhin, A.N. Photochemical and photophosphorylation activities of chloroplasts and leaf mesostructure in Chinese cabbage plants grown under illumination with light-emitting diodes. Russ. J. Plant Physiol. 2010, 57, 382-391. [CrossRef]

99. Ouzounis, T.; Fretté, X.; Rosenqvist, E.; Ottosen, C.O. Spectral effects of supplementary lighting on the secondary metabolites in roses, chrysanthemums, and campanulas. J. Plant Physiol. 2014, 171, 1491-1499. [CrossRef] [PubMed]

100. Wang, Y.; Noguchi, K.; Terashima, I. Photosynthesis-dependent and independent responses of stomata to blue, red and green monochromatic light: Differences between the normally oriented and inverted leaves of sunflower. Plant Cell Physiol. 2011, 52, 479-489. [CrossRef] [PubMed]

101. Muneer, S.; Kim, E.J.; Park, J.S.; Lee, J.H. Influence of green, red and blue light emitting diodes on multiprotein complex proteins and photosynthetic activity under different light intensities in lettuce leaves (Lactuca sativa L.). Int. J. Mol. Sci. 2014, 15, 4657-4670. [CrossRef] [PubMed]

102. Matsuda, R.; Ohashi-Kaneko, K.; Fujiwara, K.; Goto, E.; Kurata, K. Photosynthetic characteristics of rice leaves grown under red light with or without supplemental blue light. Plant Cell Physiol. 2004, 45, 1870-1874. [CrossRef] 
103. Hattori, T.; Sonobe, K.; Inanaga, S.; An, P.; Wataru, T.; Hideki, A.; Eneji, E.A.; Shigenori, M. Short term stomatal response to light intensity changes and osmotic stress in sorghum seedlings raised with and without silicon. Environ. Exp. Bot. 2007, 60, 177-182. [CrossRef]

104. Kim, H.H.; Wheeler, R.M.; Sager, J.C.; Goins, G.D.; Norikane, J.H. Evaluation of lettuce growth using supplemental green light with red and blue light-emitting diodes in a controlled environment-A review of research at Kennedy Space Center. Acta Hortic. 2006, 711, 111-119. [CrossRef]

105. Fernandez, V.; Eichert, T.; del Rio, V.; Lopez-Casado, G.; Heredia-Guerrero, J.A.; Anunciacion, A.; Heredia, A.; Abadia, J. Leaf structural changes associated with iron deficiency chlorosis in field-grown pear and peach: Physiological implications. Plant Soil 2008, 311, 161-172. [CrossRef]

106. Stitt, M.; Schulze, D. Does RuBisCO control the rate of photosynthesis and plant growth? An exercise in molecular Ecophysiology. Plant Cell Environ. 1994, 17, 465-487. [CrossRef]

107. Briat, J.F.; Curie, C.; Gaymard, F. Iron utilization and metabolism in plants. Curr. Opin. Plant Biol. 2007, 10, 276-282. [CrossRef] [PubMed]

108. Streck, N.A. Climate change and agroecosystems: The effect of elevated atmospheric $\mathrm{CO}_{2}$ and temperature on crop growth, development, and yield. Ciênc. Rural. 2005, 35, 730-740. [CrossRef]

109. Merilo, E.; Jõesaar, I.; Brosché, M.; Kollist, H. To open or to close: Species-specific stomatal responses to simultaneously applied opposing environmental factors. New Phytol. 2014, 202, 499-508. [CrossRef]

110. Wang, F.F.; Lian, H.L.; Kang, C.Y.; Yang, H.Q. Phytochrome B is involved in mediating red light-induced stomatal opening in Arabidopsis thaliana. Mol. Plant 2010, 3, 246-259. [CrossRef] [PubMed]

111. O'Carrigan, A.; Babla, M.; Wang, F.; Liu, X.; Mak, M.; Thomas, R.; Bellotti, B.; Chen, Z.H. Analysis of gas exchange, stomatal behavior and micronutrients uncovers dynamic response and adaptation of tomato plants to monochromatic light treatments. Plant Physiol. Biochem. 2014, 82, 105-115. [CrossRef]

112. Shimazaki, K.-I.; Doi, M.; Assmann, S.M.; Kinoshita, T. Light regulation of stomatal movement. Ann. Rev. Plant Biol. 2007, 58, 219-247. [CrossRef]

113. Wang, Y.; Noguchi, K.; Ono, N.; Inoue, S.-I.; Terashima, I.; Kinoshita, T. Overexpression of plasma membrane $\mathrm{H}^{+}$-ATPase in guard cells promotes light-induced stomatal opening and enhances plant growth. Proc. Natl. Acad. Sci. USA 2014, 111, 533-538. [CrossRef]

114. Yamauchi, S.; Takemiya, A.; Sakamoto, T.; Kurata, T.; Tsutsumi, T.; Kinoshita, T.; Shimazaki, K. The Plasma Membrane H ${ }^{+}$-ATPase AHA1 Plays a major role in stomatal opening in response to blue light. Plant Physiol. 2016, 171, 2731-2743. [CrossRef]

115. Zhao, R.; Dielen, V.; Kinet, J.M.; Boutry, M. Cosuppression of a plasma membrane $\mathrm{H}^{+}$-ATPase isoform impairs sucrose translocation, stomatal opening, plant growth, and male fertility. Plant Cell 2000, 12, 535-546. [PubMed]

116. Janicka-Russak, M.; Kabała, K.; Burzyński, M.; Kłobus, G. Response of plasma membrane $\mathrm{H}^{+}$-ATPase to heavy metal stress in Cucumis sativus roots. J. Exp. Bot. 2008, 59, 3721-3728. [CrossRef]

117. Chen, C.; Xiao, Y.G.; Li, X.; Ni, M. Light-regulated stomatal aperture in Arabidopsis. Mol. Plant 2012, 5, 40-46. [CrossRef] [PubMed]

118. Liu, Y.; Ren, X.; Jeong, B.R. Carbon dioxide enrichment combined with supplemental light improve growth and quality of plug seedlings of Astragalus membranaceus Bunge and Codonopsis lanceolata Benth. Agronomy 2019, 9, 715. [CrossRef]

119. Horrer, D.; Flütsch, S.; Pazmino, D.; Matthews, J.S.A.; Thalmann, M.; Nigro, A.; Leonhardt, N.; Lawson, T.; Santelia, D. Blue light induces a distinct starch degradation pathway in guard cells for stomatal opening. Curr. Biol. 2016, 26, 362-370. [CrossRef]

120. Wang, J.; Lu, W.; Tong, Y.X.; Yang, Q.C. Leaf morphology, photosynthetic performance, chlorophyll fluorescence, stomatal development of lettuce (Lactuca sativa L.) exposed to different ratios of red light to blue light. Front. Plant Sci. 2016, 7, 250. [CrossRef]

121. Doi, M.; Kitagawa, Y.; Shimazaki, K.I. Stomatal blue light response is present in early vascular plants. Plant Physiol. 2015, 169, 1205-1213. [CrossRef]

122. Tennessen, D.J.; Singsaas, E.L.; Sharkey, T.D. Light-emitting diodes as a light source for photosynthesis research. Photosynth. Res. 1994, 39, 85-92. [CrossRef] [PubMed]

123. Park, Y.G.; Park, J.E.; Hwang, S.J.; Jeong, B.R. Light source and CO2 concentration affect growth and anthocyanin content of lettuce under controlled environment. Hortic. Environ. Biotechnol. 2012, 53, 460-466. [CrossRef]

124. Kang, C.Y.; Lian, H.L.; Wang, F.F.; Huang, J.R.; Yang, H.Q. Cryptochromes, phytochromes, and COP1 regulate light-controlled stomatal development in Arabidopsis. Plant Cell 2009, 21, 2624-2641. [CrossRef]

125. Von Wettstein, D.; Gough, S.; Kannangara, C.G. Chlorophyll biosynthesis. Plant Cell 1995, 7, 1039-1057. [CrossRef]

126. Wade, H.K.; Bibikova, T.N.; Valentine, W.J.; Jenkins, G.I. Interactions within a network of phytochrome, cryptochrome and UV-B phototransduction pathways regulate chalcone synthase gene expression in Arabidopsis leaf tissue. Plant J. 2001, 25, 675-685. [CrossRef] [PubMed]

127. Kopsell, D.A.; Sams, C.E.; Barickman, T.C.; Morrow, R.C. Sprouting broccoli accumulate higher concentrations of nutritionally important metabolites under narrow-band light-emitting diode lighting. J. Am. Soc. Hortic. Sci. 2014, 139, 469-477. [CrossRef]

128. Jilani, A.; Kar, S.; Bose, S.; Tripathy, B.C. Regulation of the carotenoid content and chloroplast development by levulinic acid. Physiol. Plant. 1996, 96, 139-145. [CrossRef] 
129. Hoober, J.K.; Eggink, L.L. Assembly of light-harvesting complex II and biogenesis of thylakoid membranes in chloroplasts. Photosynth. Res. 1999, 61, 197-215. [CrossRef]

130. Poudel, P.R.; Kataoka, I.; Mochioka, R. Effect of red-and bluelight-emitting diodes on growth and morphogenesis of grapes. Plant Cell Tissue Organ Cult. 2008, 2, 147-153. [CrossRef]

131. Kurilcik, A.; Canova, M.R.; Dapkuniene, S.; Zilinskaite, S.; Kurilcik, G. In vitro culture of Chrysanthemum plantlets using light emitting diodes. Cent. Eur. J. Biol. 2008, 2, 161-167. [CrossRef]

132. Sood, S.; Gupta, V.; Tripathy, B.C. Photoregulation of the greening process of wheat seedlings grown in red light. Plant Mol. Biol. 2005, 59, 269-287. [CrossRef]

133. Erwin, J.E.; Warner, R.M. Determination of photoperiodic response group and effect of supplemental irradiance on flowering of several bedding plant species. Acta Hortic. 2002, 580, 95-99. [CrossRef]

134. Runkle, E.S.; Heins, R.D. Manipulating the light environment to control flowering and morphogenesis of herbaceous plants. Acta Hortic. 2006, 711, 51-59. [CrossRef]

135. Vince, D. The regulation of flowering in long-day plants. Acta Hortic. 1969, 14, 91-95. [CrossRef]

136. Runkle, E.S.; Heins, R.D. Specific functions of red, far red, and blue light in flowering and stem extension of long-day plants. J. Am. Soc. Hortic. Sci. 2001, 12, 275-282. [CrossRef]

137. Nissim-Levi, A.; Kitron, M.; Nishri, Y.; Ovadia, R.; Forer, I.; Oren-Shamir, M. Effects of blue and red LED lights on growth and flowering of Chrysanthemum morifolium. Sci. Hortic. 2019, 254, 77-83. [CrossRef]

138. Higuchi, Y.; Narumi, T.; Oda, A.; Nakano, Y.; Sumitomo, K.; Fukai, S.; Hisamatsu, T. The gated induction system of a systemic floral inhibitor, antiflorigen, determines obligate short-day flowering in chrysanthemums. Proc. Natl. Acad. Sci. USA 2013, 110, 17137-17142. [CrossRef] [PubMed]

139. Jeong, S.W.; Park, S.; Jin, J.S.; Seo, O.N.; Kim, G.S.; Kim, Y.H.; Bae, H.; Lee, G.; Kim, S.T.; Lee, W.S.; et al. Influences of four different light-emitting diode lights on flowering and polyphenol variations in the leaves of chrysanthemum (Chrysanthemum morifolium). J. Agric. Food Chem. 2012, 60, 9793-9800. [CrossRef] [PubMed]

140. Yoshida, H.; Hikosaka, S.; Goto, E.; Takasuna, H.; Kudou, T. Effects of light quality and light period on flowering of everbearing strawberry in a closed plant production system. Acta Hortic. 2012, 956, 107-112. [CrossRef]

141. Yoshida, H.; Mizuta, D.; Fukuda, N.; Hikosaka, S.; Goto, E. Effects of varying light quality from single-peak blue and red light-emitting diodes during nursery period on flowering, photosynthesis, growth, and fruit yield of ever bearing strawberry. Plant Biotechnol. 2016, 33, 267-276. [CrossRef] [PubMed]

142. Sumitomo, K.; Higuchi, Y.; Aoki, K.; Miyamae, H.; Oda, A.; Ishiwata, M.; Yamada, M.; Nakayama, M.; Hisamatsu, T. Spectral sensitivity of flowering and FT-like gene expression in response to night break light treatments in the chrysanthemum cultivar, Reagan'. J. Hortic. Sci. Biotechnol. 2012, 87, 461-469. [CrossRef]

143. Bavrina, T.V.; Lozhnikova, V.N.; Čulafič, S.; Zhivanovich, B. Flowering of cultivated green and SAN 9789-treated Chenopodium rubrum plants exposed to white, blue and red light. Russian J. Plant Physiol. 2002, 49, 516-520.

144. Liao, Y.; Suzuki, K.; Yu, W.; Zhuang, D.; Takai, Y.; Ogasawara, R.; Shimazu, T.; Fukui, H. Night break effect of LED light with different wavelengths on floral bud differentiation of chrysanthemum morifolium Ramat 'Jimba' and Iwa no hakusen. Environ. Control Biol. 2014, 52, 45-50. [CrossRef]

145. Magar, Y.G.; Ohyama, K.; Noguchi, A.; Amaki, W.; Furufuji, S. Effects of light quality during supplemental lighting on the flowering in an everbearing strawberry. In XIII International Symposium on Plant Bioregulators in Fruit Production 1206; ISHS: Leuven, Belgium, 2018; pp. 279-284. [CrossRef]

146. Heo, J.W.; Lee, C.W.; Murthy, H.N.; Paek, K.Y. Influence of light quality and photoperiod on flowering of Cyclamen persicum Mill. cv. 'Dixie White'. Plant Growth Regul. 2003, 40, 7-10. [CrossRef]

147. Senger, H.; Schmidt, W. Cryptochrome and UV receptors. In Photomorphogeneis in Plants; Kendrick, R.E., Kronenberg, G.H.M., Eds.; Mortinus Nijhoff Publishers: Dordrecht, The Netherlands, 1986; pp. 137-158.

148. Suarez-Lopez, P.; Wheatley, K.; Robson, F.; Onouchi, H.; Valverde, F.; Coupland, G. CONSTANS mediates between the circadian clock and the control of flowering in Arabidopsis. Nature 2001, 410, 1116-1120. [CrossRef] [PubMed]

149. Bonhomme, F.; Kurz, B.; Melzer, S.; Bernier, G.; Jacqmard, A. Cytokinin and gibberellin activate SaMADS A, a gene apparently involved in regulation of the floral transition in Sinapis alba. Plant J. 2000, 24, 103-111. [CrossRef]

150. Bernier, G.; Périlleux, C. A physiological overview of the genetics of flowering time control. Plant Biotechnol. J. 2005, 3, 3-16. [CrossRef]

151. Ubukawa, M.; Fukuda, N.; Oyama-Okubo, N.; Koshioka, M.; Mander, L.N.J.; Sase, S.; Nishimura, S. Effect of light source and quality on endogenous gibberellin level and GA3 response of petunia (Petunia $\times$ hybrida Vilm.). J. Jpn. Soc. Hortic. Sci. 2004, 73, 441-446. [CrossRef]

152. Fukuda, N.; Ajima, C.; Yukawa, T.; Olsen, J.E. Antagonistic action of blue and red light on shoot elongation in petunia depends on gibberellin, but the effects on flowering are not generally linked to gibberellin. Environ. Exp. Bot. 2015, 121, 102-111. [CrossRef]

153. Fukuda, N.; Yoshida, T.; Olsen, J.E.; Senaha, C.; Jikumaru, Y.; Kamiya, Y. Short main shoot length and inhibition of floral bud development under red light can be recovered by application of gibberellin and cytokinin. Acta Hortic. 2012, 956, $215-222$. [CrossRef]

154. Mills-Ibibofori, T.; Dunn, B.L.; Maness, N.; Payton, M. Effect of LED Lighting and Gibberellic Acid Supplementation on Potted Ornamentals. Horticulturae 2019, 5, 51. [CrossRef] 
155. Yamaguchi, S.; Kamiya, Y. Gibberellins and light-simulated seed germination. J. Plant Growth Regul. 2001, 20, 369-376. [CrossRef] [PubMed]

156. Williams, E.A.; Morgan, P.W. Floral initiation in sorghum hastened by gibberellic acid and far-red light. Planta 1979, 145, $269-272$. [CrossRef]

157. Lin, C. Photoreceptors and regulation of flowering time. Plant Physiol. 2000, 123, 39-50. [CrossRef] [PubMed]

158. D'Aloia, M.; Bonhomme, D.; Bouché, F.; Tamseddak, K.; Ormenese, S.; Torti, S.; Coupland, G.; Périlleux, C. Cytokinin promotes flowering of Arabidopsis via transcriptional activation of the FT paralogue TSF. Plant J. 2011, 65, 972-979. [CrossRef]

159. Fukuda, N.; Ishii, Y.; Ezura, H.; Olsen, J.E. Effects of light quality under red and blue light emitting diodes on growth and expression of FBP28 in petunia. Acta Hortic. 2011, 907, 361-366. [CrossRef]

160. Yamada, A.; Tanigawa, T.; Suyama, T.; Matsuno, T.; Kunitake, T. Night break treatment using different light sources promotes or delays growth and flowering of Eustoma grandiflorum (Raf.) Shinn. J. Jpn. Soc. Hortic. Sci. 2008, 77, 69-74. [CrossRef]

161. Park, I.S.; Cho, K.J.; Kim, J.; Cho, J.Y.; Lim, T.J.; Oh, W. Growth and flowering responses of petunia to various artificial light sources with different light qualities. Korean J. Hortic. Sci. Technol. 2016, 34, 55-66.

162. Vince-Prue, D.; Canham, A.E. Horticultural significance of photomorphogenesis. In Encyclopedia of Plant Physiology; Shropshire, W., Mohr, H., Eds.; Springer-Verlag: Berlin, Germany, 1983; pp. 518-544.

163. Hamamoto, H.; Hideo, S.; Tadahisa, H. Budding response of horticultural crops to night break with red light on alternate days. Environ. Control Biol. 2005, 43, 21-27. [CrossRef]

164. Blanchard, M.G.; Runkle, E.S. Intermittent light from a rotating high-pressure sodium lamp promotes flowering of long-day plants. HortScience 2010, 45, 236-241. [CrossRef]

165. Park, Y.G.; Muneer, S.; Jeong, B.R. Morphogenesis, flowering, and gene expression of Dendranthema grandiflorum in response to shift in light quality of night interruption. Int. J. Mol. Sci. 2015, 16, 6497-16513. [CrossRef] [PubMed]

166. Vince-Prue, D. Photoperiodism in Plants, 1st ed.; McGraw-Hill: London, UK, 1975.

167. Kim, Y.J.; Lee, H.J.; Kim, K.S. Night interruption promotes vegetative growth and flowering of Cymbidium. Sci. Hortic. 2011, 130, 887-893. [CrossRef]

168. Tong, Z.; Wang, T.; Xu, Y. Evidence for involvement of phytochrome regulation in male sterility of a mutant of Oryza sativa L. Photochem. Photobiol. 1990, 52, 161-164. [CrossRef]

169. Bagnall, D.J.; King, R.W.; Hangarter, R.P. Blue-light promotion of flowering is absent in hy4 mutants of Arabidopsis. Planta 1996, 200, 278-280. [CrossRef]

170. Craig, D.S.; Runkle, E.S. An intermediate phytochrome photoequilibria from night-interruption lighting optimally promotes flowering of several long-day plants. Environ. Exp. Bot. 2016, 121, 132-138. [CrossRef]

171. Higuchi, Y.; Sumitomo, K.; Oda, A.; Shimizu, H.; Hisamatsu, T. Days light quality affects the night-break response in the short-day plant chrysanthemum, suggesting differential phytochrome-mediated regulation of flowering. J. Plant Physiol. 2012, 169, 1789-1796. [CrossRef]

172. Park, Y.G.; Muneer, S.; Soundararajan, P.; Manivnnan, A.; Jeong, B.R. Light quality during night interruption affects morphogenesis and flowering in geranium. Hortic. Environ. Biotechnol. 2017, 58, 212-217. [CrossRef]

173. Mockler, T.C.; Guo, H.; Yang, H.; Duong, H.; Lin, C. Antagonistic actions of Arabidopsis cryptochromes and phytochrome B in the regulation of floral induction. Development 1999, 126, 2073-2082. [PubMed]

174. Mockler, T.; Yang, H.; Yu, W.; Parikh, D.; Cheng, Y.; Dolan, S.; Lin, C. Regulation of photoperiodic flowering by Arabidopsis photoreceptors. Proc. Natl. Acad. Sci. USA 2003, 100, 2140-2145. [CrossRef] [PubMed]

175. Carre, I.A. Genetic dissection of the photoperiod sensing mechanism in the long-day plant Arabidopsis thaliana. In Biological Rhythms and Photoperiodism in Plants; Lumsden, P.J., Millar, A.J., Eds.; BIOS Scientific Publishers: Oxford, UK, 1998; pp. 257-269.

176. Park, Y.G.; Jeong, B.R. Both the Quality and Positioning of the Night Interruption Light are Important for Flowering and Plant Extension Growth. J. Plant Growth Regul. 2019, 39, 583-593. [CrossRef]

177. Park, Y.G.; Oh, H.J.; Jeong, B.R. Growth and anthocyanin concentration of Perilla frutescens var. acuta Kudo as affected by light source and DIF under controlled environment. Hortic. Environ. Biotechnol. 2013, 54, 103-108. [CrossRef]

178. Kang, D.; Jeong, H.K.; Park, Y.G.; Jeong, B.R. Flowering and Morphogenesis of Kalanchoe in Response to Quality and Intensity of Night Interruption Light. Plants 2019, 8, 90. [CrossRef]

179. Song, Y.H.; Ito, S.; Imaizumi, T. Flowering time regulation: Photoperiod- and temperature-sensing in leaves. Trends Plant Sci. 2013, 18, 575-583. [CrossRef]

180. Fukuda, N. Advanced light control technologies in protected horticulture: A review of morphological and physiological responses in plants to light quality and its application. J. Dev. Sustain. Agric. 2013, 8, 32-40.

181. Zeevaart, J.A.D. Leaf-produced floral signals. Curr. Opin. Plant Biol. 2008, 1, 541-547. [CrossRef]

182. Franklin, K.A.; Praekelt, U.; Stoddart, W.M.; Billingham, O.E.; Halliday, K.J.; Whitelam, G.C. Phytochromes B, D, and E act redundantly to control multiple physiological responses in Arabidopsis. Plant Physiol. 2003, 131, 1340-1346. [CrossRef]

183. Park, Y.G.; Jeong, B.R. Night interruption light quality changes morphogenesis, flowering and gene expression in Dendranthema grandiflorum. Hortic. Environ. Biotechnol. 2019, 60, 167-173. [CrossRef]

184. Lü, J.M.; Lin, P.H.; Yao, Q.; Chen, C. Chemical and molecular mechanisms of antioxidants: Experimental approaches and model systems. J. Cell. Mol. Med. 2010, 14, 840-860. [CrossRef] [PubMed]

185. Wink, M. Modes of Action of Herbal Medicines and Plant Secondary Metabolites. Medicines 2015, 2, 251-286. [CrossRef] 
186. Venkatachalam, S.R.; Chattopadhyay, S. Natural radioprotective agents: An overview. Curr. Org. Chem. $2005,9,389-404$. [CrossRef]

187. Wheeler, R.M.; Stutte, G.W.; Subbarao, G.V.; Yorio, N.C. Plant growth and human life support for space travel. In Handbook of Plant and Crop Physiology, 2nd ed.; Pessarakli, M., Ed.; Marcel Dekker: New York, NY, USA, 2002; pp. $925-941$.

188. Zhang, H.; Tsao, R. Dietary polyphenols, oxidative stress and antioxidant and anti-inflammatory effects. Curr. Opin. Food Sci. 2016, 8, 33-42. [CrossRef]

189. Meng, X.; Xing, T.; Wang, X. The role of light in the regulation of anthocyanin accumulation in Gerbera hybrid. Plant Growth Regul. 2004, 44, 243-250. [CrossRef]

190. Dutta Gupta, S.; Pradhan, S. Regulation of Gene Expression by LED Lighting. In Light Emitting Diodes for Agriculture; Dutta Gupta, S., Ed.; Springer: Singapore, 2017; pp. 237-258.

191. Hasan, M.M.; Bashir, T.; Ghosh, R.; Lee, S.K.; Bae, H. An Overview of LEDs' Effects on the Production of Bioactive Compounds and Crop Quality. Molecules 2017, 22, 1420. [CrossRef] [PubMed]

192. Brazaityte, A.; Sakalauskiene, S.; Samuoliene, G.; Jankauskiene, J.; Viršile, A.; Novičkovas, A.; Sirtautas, R.; Miliauskiene, J.; Vaštakaite, V.; Dabašinskas, L.; et al. The effects of LED illumination spectra and intensity on carotenoid content in Brassicaceae microgreens. Food Chem. 2015, 173, 600-606. [CrossRef]

193. Samuoliene, G.; Viršile, A.; Brazaityte, A.; Jankauskiene, J.; Sakalauskiene, S.; Vaštakaite, V.; Novičkovas, A.; Viškeliene, A.; Sasnauskas, A.; Duchovskis, P. Blue light dosage affects carotenoids and tocopherols in microgreens. Food Chem. 2017, 228, 50-56. [CrossRef] [PubMed]

194. Liu, Y.; Roof, S.; Ye, Z.; Barry, C.; van Tuinen, A.; Vrebalov, J.; Bowler, C.; Giovannoni, J. Manipulation of light signal transduction as a means of modifying fruit nutritional quality in tomato. Proc. Natl. Acad. Sci. USA 2004, 101, 9897-9902. [CrossRef]

195. Wu, J.; Liu, W.; Yuan, L.; Guan, W.Q.; Brennan, C.S.; Zhang, Y.Y.; Zhang, J.; Wang, Z.D. The influence of postharvest UV-C treatment on anthocyanin biosynthesis in fresh-cut red cabbage. Sci. Rep. 2017, 7, 5232. [CrossRef]

196. Sharma, P.; Jha, A.B.; Dubey, R.S.; Pessarakli, M. Reactive oxygen species, oxidative damage, and antioxidative defense mechanism in plants under stressful conditions. J. Bot. 2012, 2012, 1-26. [CrossRef]

197. Wei, H.; Wang, M.; Jeong, B.R. Effect of supplementary lighting duration on growth and activity of antioxidant enzymes in grafted watermelon seedlings. Agronomy 2020, 10, 337. [CrossRef]

198. Lee, S.C.; Kim, J.M.; Jeong, S.M.; Kim, D.R.; Ha, J.U.; Nam, K.C. Effect of far-infrared radiation on the antioxidant activity of rice Hulls. J. Agric. Food Chem. 2003, 51, 4400-4403. [CrossRef] [PubMed]

199. Meir, S.; Kanner, J.; Akiri, B.; Philosoph, H.S. Determination and involvement of aqueous reducing compounds in oxidative defense systems of various senescing leaves. J. Agric. Food Chem. 1995, 43, 1813-1819. [CrossRef]

200. Hayat, S.; Hayat, Q.; Alyemeni, M.N.; Wani, A.S.; Pichtel, J. Role of proline under changing environments: A review. Plant Signal. Behav. 2012, 7, 1456-1466. [CrossRef]

201. Vaštakaitè, V.; Viršilè, A.; Brazaitytè, A.; Samuolienè, G.; Jankauskienė, J.; Sirtautas, R.; Novičkovas, A.; Dabašinskas, L.; Sakalauskienè, S.; Miliauskienè, J. The Effect of Blue Light Dosage on Growth and Antioxidant Properties of Microgreens. Sodinink. Daržinink. 2015, 34, 25-35.

202. Azad, M.O.K.; Kim, W.W.; Park, C.H.; Cho, D.H. Effect of Artificial LED Light and Far Infrared Irradiation on Phenolic Compound, Isoflavones and Antioxidant Capacity in Soybean (Glycine max L.) Sprout. Foods 2018, 7, 174. [CrossRef] [PubMed]

203. Wei, H.; Liu, C.; Hu, J.; Jeong, B.R. Quality of supplementary morning lighting (SML) during propagation period affects physiology, stomatal characteristics, and growth of strawberry plants. Plants 2020, 9, 638. [CrossRef] [PubMed]

204. Kopsell, D.A.; Lefsrud, M.; Kopsell, D. Pre-harvest cultural growing conditions can influence carotenoid phytochemical concentrations in vegetable crops. In Proceedings of the II International Symposium on Human Health Effects of Fruits and Vegetables: FAVHEALTH 2007, Houston, TX, USA, 9-13 October 2007; Patil, B., Ed.; ISHS: Leuven, Belgium, 2007; pp. $283-294$.

205. Alrifai, O.; Hao, X.; Marcone, M.F.; Tsao, R. Current review of the modulatory effects of LED lights on photosynthesis of secondary metabolites and future perspectives of microgreen vegetables. J. Agric. Food Chem. 2019, 67, 6075-6090. [CrossRef]

206. Tsao, R.; Wang, M.; Deng, Z. Lutein: Separation, Antioxidant Activity, and Potential Health Benefits. Antioxid. Meas. Appl. Am. Chem. Soc. 2007, 956, 352-372.

207. Meyers, K.J.; Johnson, E.J.; Bernstein, P.S.; Iyengar, S.K.; Engelman, C.D.; Karki, C.K.; Liu, Z.; Igo, R.P.; Truitt, B.; Klein, M.L.; et al. Genetic determinants of macular pigments in women of the Carotenoids in Age-Related Eye Disease Study. Investig. Ophthalmol. Vis. Sci. 2013, 54, 2333-2345. [CrossRef] [PubMed]

208. Fleshman, M.K.; Lester, G.E.; Riedl, K.M.; Kopec, R.E.; Narayanasamy, S.; Curley, R.W., Jr. Carotene and novel apocarotenoid concentrations in orange-fleshed Cucumis melo melons: Determinations of $\beta$-carotene bio accessibility and bioavailability. J. Agric. Food Chem. 2011, 59, 4448-4454. [CrossRef]

209. Kopsell, D.A.; Sams, C.E.; Morrow, R.C. Blue wavelengths from led lighting increase nutritionally important metabolites in specialty crops. Hortic. Sci. 2015, 50, 1285-1288. [CrossRef]

210. Ohashi-Kaneko, K.; Takase, M.; Kon, N.; Fujiwara, K.; Kurata, K. Effect of light quality on growth and vegetable quality in leaf lettuce, spinach and komatsuna. Environ. Control Biol. 2007, 45, 189-198. [CrossRef]

211. Ma, Y.Z.; Holt, N.E.; Li, X.P.; Niyogi, K.K.; Fleming, G.R. Evidence for direct carotenoid involvement in the regulation of photosynthetic light harvesting. Proc. Natl. Acad. Sci. USA 2003, 100, 4377-4382. [CrossRef] 
212. He, J.; Qin, L.; Chong, E.L.C.; Choong, T.W.; Lee, S.K. Plant Growth and Photosynthetic Characteristics of Mesembryanthemum crystallinum Grown Aeroponically under Different Blue- and Red-LEDs. Front. Plant Sci. 2017, 17, 61. [CrossRef]

213. Metallo, R.M.; Kopsell, D.A.; Sams, C.E.; Bumgarner, N.R. Influence of blue/red vs. white LED light treatments on biomass, shoot morphology, and quality parameters of hydroponically grown kale. Sci. Hortic. 2018, 235, 189-197. [CrossRef]

214. King, A.; Young, G. Characteristics and occurrence of phenolic phytochemicals. J. Am. Dietician Assoc. 1999, 99, $213-218$. [CrossRef]

215. Reddy, C.V.K.; Sreeramulu, D.; Raghunath, M. Antioxidant activity of fresh and dry fruits commonly consumed in India. Food Res. Int. 2010, 43, 285-288. [CrossRef]

216. Someya, S.; Yoshiki, Y.; Okubo, K. Antioxidant compounds from bananas (Musa Cavendish). Food Chem. 2002, 79, 351-354. [CrossRef]

217. Connor, A.M.; Finn, C.E.; Alspach, P.A. Genotypic and environmental variation in antioxidant activity and total phenolic content among blackberry and hybrid berry cultivars. J. Am. Soc. Hortic. Sci. 2005, 130, 527-533. [CrossRef]

218. Minatel, I.O.; Borges, C.V.; Ferreira, H.A.; Chen, C.O.; Lima, G.P. Phenolic Compounds: Functional Properties, Impact of Processing and Bioavailability. In Phenolic Compounds-Biological Activity; Soto-Hernández, M., Palma-Tenango, M., GarcíaMateos, R., Eds.; InTech: London, UK, 2017; pp. 1-24.

219. Lobiuc, A.; Vasilache, V.; Oroian, M.; Stoleru, T.; Burducea, M.; Pintilie, O.; Zamfirache, M.M. Blue and Red LED Illumination Improves Growth and Bioactive Compounds Contents in Acyanic and Cyanic Ocimum basilicum L. microgreens. Molecules 2017, 22, 2111. [CrossRef]

220. Liu, H.; Chen, Y.; Hu, T.; Zhang, S.; Zhang, Y.; Zhao, T.; Yu, H.; Kang, Y. The influence of light-emitting diodes on the phenolic compounds and antioxidant activities in pea sprouts. J. Funct. Foods 2016, 25, 459-465. [CrossRef]

221. Nam, T.G.; Kim, D.O.; Eom, S.H. Effects of light sources on major flavonoids and antioxidant activity in common buckwheat sprouts. Food Sci. Biotechnol. 2018, 27, 169-176. [CrossRef]

222. Taulavuori, K.; Taulavuori, E.; Pyysalo, A.; Julkunen-Tiitto, R. Responses of phenolic acid and flavonoid synthesis to blue and blue violet light depends on plant species. Environ. Exp. Bot. 2018, 150, 183-187. [CrossRef]

223. Cevallos-Casals, B.A.; Cisneros-Zevallos, L. Impact of germination on phenolic content and antioxidant activity of 13 edible seed species. Food Chem. 2010, 119, 1485-1490. [CrossRef]

224. Lee, S.J.; Ahn, J.K.; Khanh, T.D.; Chun, S.C.; Kim, S.L.; Ro, H.M.; Song, H.K.; Chung, I.M. Comparison of Isoflavone Concentrations in Soybean (Glycine max (L.) Merrill) Sprouts Grown under Two Different Light Conditions. J. Agric. Food Chem. 2007, 55, 94159421. [CrossRef]

225. Liu, Y.; Fang SYang, W.; Shang, X.; Fu, X. Light quality affects flavonoid production and related gene expression in Cyclocarya paliurus. J. Photochem. Photobiol. B 2018, 179, 66-73. [CrossRef] [PubMed]

226. Gould, K.S. Nature's Swiss Army knife: The diverse protective roles of anthocyanins in leaves. J. Biomed. Biotechnol. 2004, 5, 314-320. [CrossRef] [PubMed]

227. Cartea, M.E.; Francisco, M.; Soengas, P.; Velasco, P. Phenolic compounds in Brassica vegetables. Molecules 2011, 16, 251-280. [CrossRef] [PubMed]

228. Qian, H.; Liu, T.; Deng, M.; Miao, H.; Cai, C.; Shen, W.; Wang, Q. Effects of light quality on main health-promoting compounds and antioxidant capacity of Chinese kale sprouts. Food Chem. 2016, 196, 1232-1238. [CrossRef]

229. Ahmad, M.; Cashmore, A.R. The blue-light receptor cryptochrome shows functional dependence on phytochrome A or phytochrome B in Arabidopsis thaliana. Plant J. 1997, 11, 421-427. [CrossRef] [PubMed]

230. Zhang, T.; Folta, K.M. Green light signaling and adaptive response. Plant Signal. Behav. 2012, 7, 75-78. [CrossRef]

231. Kennedy, A.R.; Todd, P. Biological countermeasures in space radiation health. Gravit. Space Biol. Bull. 2003, 16, 37-44. [PubMed]

232. Bhatia, A.; Jain, M. Spinacia oleracea L. protects against gamma radiations: A study on glutathione and lipid peroxidation in mouse liver. Phytomedicine 2004, 11, 607-615. [CrossRef] [PubMed] 